Research paper

\title{
An innovative window heat recovery (WHR) system with heat pipe technology: Analytical, CFD, experimental analysis and building retrofit performance
}

\author{
Germilly Barreto $^{\mathrm{a}}, \mathrm{Ke}_{\mathrm{Qu}}{ }^{\mathrm{b}, *}$, Yuhao Wang $^{\mathrm{b}}$, Muriel Iten ${ }^{\mathrm{a}}$, Saffa Riffat ${ }^{\mathrm{b}}$ \\ a Low Carbon E' Resource Efficiency, REDi, Instituto de Soldadura e Qualidade, 4415-491 Grijó, Portugal \\ ${ }^{\mathrm{b}}$ Department of Architecture and Built Environment, The University of Nottingham, University Park, Nottingham, NG7 2RD, UK
}

\section{A R T I C L E I N F O}

\section{Article history:}

Received 29 October 2021

Received in revised form 13 December 2021

Accepted 10 February 2022

Available online $\mathrm{xxxx}$

\section{Keywords:}

Building ventilation

Heat recovery

Window heat recovery

Heat pipe

Energy performance

Thermal comfort

\begin{abstract}
A B S T R A C T
This paper addresses the numerical and experimental performance analysis of a windows heat recovery system made of heat pipes. For modelling, the heat pipe is considered as a pseudo solid material with high value of effective thermal conductivity. An experimental investigation using a window heat recovery prototype was carried out to predict the value of effective thermal conductivity of the heat pipes and to validate the numerical model. After validation, a parametric analysis was conducted to investigate the performance of the recovery system for different working conditions (mass flow rate and temperature difference between exhausted and supplied air). Based on the performance obtained in the parametric analysis, energy performance in building and the impact on velocity and pressure distributions are also evaluated with the support of CFD analysis. It is found that the effectiveness of window heat recovery made of heat pipes depends on ventilation rate and temperature difference between exhausted and supplied air. Increasing ventilation rates and temperature differences decrease the effectiveness. For ventilation rate between $10-60 \mathrm{~m}^{3} / \mathrm{h}$ and temperature difference $10-30{ }^{\circ} \mathrm{C}$, effectiveness between 65\%-95\% and pressure drop 4-80 Pa are obtained. For performance in building, the power consumption can be reduced between 3\%-24\% and the thermal comfort increased.
\end{abstract}

(c) 2022 The Authors. Published by Elsevier Ltd. This is an open access article under the CC BY-NC-ND license (http://creativecommons.org/licenses/by-nc-nd/4.0/).

\section{Introduction}

Energy consumption in buildings is responsible for around $40 \%$ of the total energy demand in the EU (Ekins and Lees, 2008). Building heating, cooling and ventilation represents between $40 \%-60 \%$ of the total consumption (Zender-świercz, 2021), where ventilation itself is between $20 \%-30 \%$ (National Institute for Health and Welfare, 2013). Several studies indicated that building ventilation will significantly affect occupants' health (Cao and Ren, 2018; Yuan et al., 2018), indoor air quality (Lim et al., 2021; González Couret et al., 2013), heating/cooling demand (Tien et al., 2021; Zuazua-Ros et al., 2019) and energy consumption (Young et al., 2020; Bang et al., 2019).

Occupants spend about $90 \%$ of their time on indoor activities (Li and Wang, 2020), where indoor air quality is generally poorer than outdoor air quality with $2-5$ times higher indoor airborne pollutants than the outside (Pitarma et al., 2017). Research

\footnotetext{
* Correspondence to: Buildings, Energy and Environment Research Group], University of Nottingham, Nottingham, NG7 2RD, UK.

E-mail addresses: grbarreto@isq.pt (G. Barreto), ezzkq@exmail.nottingham.ac.uk (K. Qu), ezxyw13@exmail.nottingham.ac.uk (Y. Wang), mciten@isq.pt (M. Iten), Lazsbr@exmail.nottingham.ac.uk (S. Riffat).
}

also indicates sick building syndromes (e.g., pruritus, dry cough, ocular pruritus, and headache) are attributed to poor indoor air quality, as well as diseases like extrinsic allergic alveolitis and asthma (Capristo et al., 2004).

Several studies have investigated the impact of ventilation on indoor air temperature. Three categories of key parameters (Zhang et al., 2021) will affect the ventilation efficiency, including external weather conditions, building materials and occupants' behaviours of ventilation control (day/night ventilation), ventilation rate and indoor air temperature settings. As many studies confirmed (Guerra Santin et al., 2009; Biesiot and Noorman, 1999; Fabi et al., 2012; Cho et al., 2021), the occupants' behaviour and indoor air quality are interactively influenced by each other according to the efficiency of ventilation systems.

Natural ventilation by opening windows is the most common in residential and commercial buildings, with approximately $35 \%$ additional primary energy consumption (Paone and Bacher, 2018). Many building occupants sealed their windows for security reasons, which causes virus dispersion, poor indoor air quality, damps and moulds, which cause damage to building fabric (Wood and Salib, 2013). However, to improve the indoor air quality, window opening for fresh air in the winter season caused a problem that room temperature decreases rapidly by an intake of 


\section{Nomenclature}

$A_{f}$

$A_{p}$

$A_{C}$

$A_{H}$

$C_{p}$

$D_{f}$

$D_{p}$

$d_{b t f}$

F

$f_{\text {th }}$

$h$

k

L

$\dot{m}$

$N_{f}$

$N_{P}$

$N_{S}$

\section{$\overline{\mathrm{Nu}}$}

Pr

Q

$R$

Re

$S$

\section{$T$}

V

$V_{r}$

W

$\Delta P$

\section{Greek symbols}

\section{Subscripts}

a

A

av

C

eff

$f$

H

in

out

$\mathrm{T}$

$1,2,3,4$

$$
\begin{aligned}
& \varepsilon \\
& \mu \\
& \rho
\end{aligned}
$$

Heat transfer area of a single fin $\left(\mathrm{m}^{2}\right)$

Cross section area of the heat pipe tube $\left(\mathrm{m}^{2}\right)$

Heat transfer area of cold side $\left(\mathrm{m}^{2}\right)$

Heat transfer area of hot side $\left(\mathrm{m}^{2}\right)$

Specific heat capacity $\left(\mathrm{J} \mathrm{kg}^{-1} \mathrm{~K}^{-1}\right)$

Diameter of fins (m)

Diameter of heat pipes $(\mathrm{m})$

Distance between fins $(\mathrm{m})$

Calibration factor (-)

Thickness of the fins ( $m$ )

Convective heat transfer coefficient (W $\mathrm{m}^{-2} \mathrm{~K}^{-1}$ )

Thermal conductivity $\left(\mathrm{W} \mathrm{m}^{-1} \mathrm{~K}^{-1}\right.$ )

Length $(\mathrm{m})$

Mass flow rate $\left(\mathrm{kg} \mathrm{s}^{-1}\right)$

Number of fins (-)

Number of layers of heat pipes (-)

Number of heat pipes connected in serial (-)

Average Nusselt number

Prandtl number (-)

Heat flow through heat pipe (W)

Thermal resistance $\left(\mathrm{K} \mathrm{W}^{-1}\right)$

Reynolds number $(-)$

Nondimensional distance between fins (m)

Temperature $(\mathrm{K})$

Air velocity $\left(\mathrm{m} \mathrm{s}^{-1}\right)$

Volumetric air flow rate $\left(\mathrm{m}^{3} \mathrm{~h}^{-1}\right)$

Nondimensional diameter of the fins (m)

Pressure drop

\section{Effectiveness (-) \\ Dynamic viscosity of air (Pa s) \\ Density of air $\left(\mathrm{kg} \mathrm{m}^{-3}\right)$}

Air
Adiabatic side of the heat pipe
Average values
Cold side of the heat pipe
Effective value
Fins
Hot side of the heat pipe
Inlet
Outlet
Total
Locations in mesh

cold outdoor air into the building, thereby consuming additional energy for operating heating system additionally to increase the reduced room temperature (Simonson, 2005). However, natural ventilation could still be considered an efficient and effective approach with versatile requirements than particular building types (Government, 2010). Rasheed et al. (2017) investigated the unreliability of natural ventilation system operation and the indoor air quality, thus natural ventilation in majority of buildings is insufficient to improve the indoor air quality due to these limitations. Hence, Belmans et al. (2019) found that the 'mixedmode or 'hybrid' approach could serve as efficient options for building ventilation.

In recent decades, mechanical ventilation systems have been increasingly used to meet ventilation requirements and dilute indoor-generated pollutants. Numerous studies (Kang et al., 2021; Tian et al., 2020; Yassine et al., 2012) have examined the effects of residential mechanical ventilation systems on IAQ thermal comfort, and/or energy use. Mechanical ventilation systems with heat recovery (MVHR) have become more popular as an energyefficient solution to provide good IAQ during the heating season (Clarke, 2019). However, mechanical ventilation systems are typically in operation throughout the whole year resulting in high energy consumption for operating the fan (Babota, 2014). Moreover, due to the lack of financial resources to purchase and install the MVHR system, especially in existing houses, homeowners or landlords are rarely considering this system (Krieger and Higgins, 2002). Therefore, considering the above-mentioned limitations, it is imperative to develop an energy-efficient, compact, noninstructive and easy-installed heat recovery ventilation system for building retrofit.

Heat recovery technologies can be classified using different criteria (Mardiana-Idayu and Riffat, 2012; Cuce and Riffat, 2015). For example, Mardiana-Idayu and Riffat (2012) presented a review of heat recovery technologies for building applications, where the different types are divided according to the construction type of the heat exchanger. According to them, they can be classified in fixed-plate (Shen et al., 2017; Nasif et al., 2010), rotary wheel (Calautit et al., 2020; Nóbrega and Brum, 2009), runaround (Vali et al., 2009; Wang, 1985) and heat pipes (Yau and Ahmadzadehtalatapeh, 2010; Gedik et al., 2016). Fixed plates are the most used and can achieve high values of efficiency, and the rotary wheel can recover both sensible and latent heat, while the run-around has the advantage of recovering heat from different parts of the building (Mardiana-Idayu and Riffat, 2012). Heat pipe types have some advantages concerning conventional technologies, such as being suitable for natural ventilation due to their low resistance to airflow, ability to work at the low-temperature difference, and high heat transfer rate in a small cross-section area (Mardiana-Idayu and Riffat, 2012; Shao et al., 1998). Shao et al. (1998) presented and conducted the experimental investigation of a low-pressure drop heat recovery device made of heat pipes. They studied the effect of different techniques to increase the heat transfer while not increasing the flow resistance. They found recovery efficiency around $60 \%$ and that using wire fins presents the best balance between good thermal performance and low flow resistance.

Table 1 shows the literature review of ventilation heat recovery technology application in building retrofit. Most of the research focused on the apartment block building types in cold climate countries, with heat recovery effectiveness varied between $75 \%-90 \%$. Research also indicated that applying expensive cross or counter flow enthalpy heat exchangers could achieve relatively high energy reduction rates of $23.6 \%-25 \%$ compared with the building baseline. However, the cheaper thermal rotary wheel has a $12 \%-20 \%$ lower energy reduction rate due to lower heat recovery effectiveness between $75 \%$ and $85 \%$. Moreover, these researches were limited in the assessment of the thermal comfort improvement when integrating heat recovery ventilation systems in the building retrofit packages. Furthermore, these researches also showed a gap in the heat pipe-heat recovery integrated building ventilation modelling and analysis.

This work proposed, modelled, and conducted a performance analysis of a window heat recovery system. The developed model 
Table 1

A literature review of ventilation heat recovery technology application in building retrofit.

\begin{tabular}{|c|c|c|c|c|c|c|c|}
\hline Ref. & Building type & Location & Ventilation type & Heat recovery type & $\begin{array}{l}\text { Heat recovery } \\
\text { effectiveness }\end{array}$ & $\begin{array}{l}\text { Energy reduction } \\
\text { rate }\end{array}$ & $\begin{array}{l}\text { Thermal comfort } \\
\text { improvement }\end{array}$ \\
\hline Chen et al. (2020) & Apartment block & Norway & $\begin{array}{l}\text { Mechanical ventilation } \\
\text { heat recovery (MVHR) }\end{array}$ & Flat-plate & $86 \%$ & $20.5 \%$ & $\mathrm{~N} / \mathrm{A}$ \\
\hline Dodoo (2020) & Apartment block & Sweden & $\begin{array}{l}\text { Heat recovery air } \\
\text { handling units (AHUs) }\end{array}$ & Rotary wheel & $85 \%$ & $18.1 \%$ & $\mathrm{~N} / \mathrm{A}$ \\
\hline Hall et al. (2013) & $\begin{array}{l}\text { Semi-detached } \\
\text { house }\end{array}$ & UK & $\begin{array}{l}\text { Mechanical ventilation } \\
\text { heat recovery (MVHR) }\end{array}$ & $\begin{array}{l}\text { Crossflow enthalpy } \\
\text { exchangers }\end{array}$ & $90 \%$ & $23.6 \%$ & $\checkmark$ \\
\hline $\begin{array}{l}\text { de Oliveira } \\
\text { Fernandes et al. } \\
\text { (2021) }\end{array}$ & Terraced house & Netherland & $\begin{array}{l}\text { Balanced ventilation } \\
\text { system }\end{array}$ & $\begin{array}{l}\text { Counterflow } \\
\text { enthalpy exchangers }\end{array}$ & $88 \%$ & $25 \%$ & $\mathrm{~N} / \mathrm{A}$ \\
\hline Wang et al. (2016) & Multi-family house & Sweden & $\begin{array}{l}\text { Decentralised exhaust } \\
\text { ventilation with heat } \\
\text { recovery }\end{array}$ & Rotary wheel & $80 \%$ & $12 \%$ & $\checkmark$ \\
\hline $\begin{array}{l}\text { Carlsson et al. } \\
\text { (2019) }\end{array}$ & Apartment block & Canada & $\begin{array}{l}\text { Decentralised ventilation } \\
\text { with heat recovery } \\
\text { ventilators (HRVs) }\end{array}$ & Rotary wheel & $75 \%$ & $15 \%$ & $\mathrm{~N} / \mathrm{A}$ \\
\hline $\begin{array}{l}\text { Smith and } \\
\text { Svendsen (2016) }\end{array}$ & Apartment block & Denmark & $\begin{array}{l}\text { Decentralised ventilation } \\
\text { with heat recovery } \\
\text { ventilators (HRVs) }\end{array}$ & Rotary wheel & $85 \%$ & $15 \%-20 \%$ & $\checkmark$ \\
\hline $\begin{array}{l}\text { Wallin and } \\
\text { Claesson (2014) }\end{array}$ & Apartment block & Sweden & $\begin{array}{l}\text { Heat recovery air } \\
\text { handling unit (AHU) }\end{array}$ & $\begin{array}{l}\text { Heat pump hot } \\
\text { exhaust counterflow } \\
\text { heat exchanger }\end{array}$ & $90 \%$ & $24 \%$ & $\mathrm{~N} / \mathrm{A}$ \\
\hline
\end{tabular}

is validated against experiments, and a correlation for effective thermal conductivity is proposed. The recovery unit is based on heat pipes and presents high efficiency due to the effective heat transfer in a small cross-section of heat pipes, and it has a lower pressure drop than conventional technologies, which makes this technology suitable for natural ventilation and requirement of less power for fans for application of higher ventilation rate. In addition, the system has no complex structures, which means it is easy to build and install in the building.

\section{Methodology}

This paper proposed an innovative heat pipe-based window heat recovery system as an affordable, fast-installed and noninstructive building retrofit technology to curtail heat loss caused by ventilation and improve indoor air temperature, velocity distributions, and improve thermal comfort and indoor air quality.

Fig. 1 presents the methodology flowchart used for validation and performance analysis among the analytical model, CFD simulation and the experimental results for the window heat recovery (WHR) system, where the system is described in Section 2.1 with the analytical model and CFD simulation established in Section 2.2. A 1940s' semi-detached two-bedroom house is selected as the case study to investigate the impact of the WHR system application on building energy performance and thermal comfort, with details in Section 2.3. The experiments were conducted to determine the effective thermal conductivity of the heat pipes, as described in Section 3.1. In Section 3.2, the tested heat recovery effectiveness of the WHR system was compared and validated with the analytical and CFD model simulation results. Afterwards, the parametric analysis was conducted with investigating the impacts of ventilation rate, the maximum temperature of inlet and outlet sides in parallel with the different heat pipe layers on the WHR system performances, with details discussed in Section 4.1. In addition, the building energy performances were also investigated in IES VE building simulation software, considering the impacts and relations of building monthly heating demand, different ventilation rates, space heating demand reduction rate and fan power on the WHR system, as analysed in Section 4.2. Furthermore, the vertical and horizontal air temperature and velocity differences were investigated in CFD simulation, as depicted in Section 4.3, to analyse indoor air temperature, velocity parameters distribution with the air velocity disturbance conditions. Moreover, the impact of versatile WHR ventilation rates on indoor thermal comfort was discussed in Section 4.3.

\subsection{Window heat recovery system}

Window heat recovery systems are heat exchangers coupled to building windows frame that enable to exchange heat between exhausted and supplied air during the building ventilation. This is accomplished by centrifugal fan with 6-level adjustable air speeds varied from $10 \mathrm{~m}^{3} / \mathrm{h}$ to $60 \mathrm{~m}^{3} / \mathrm{h}$. One being installed at the supply air side and another at the exhaust air outlet (Zender-świercz, 2021; Mardiana-Idayu and Riffat, 2012; Cuce and Riffat, 2015). An example of integrating the window heat recovery system in the building is presented in Fig. 2. Heat pipes have two main parts, the cold side (condenser) and the hot side (evaporator), where heat is transferred from evaporator to condenser (Cuce and Riffat, 2015). One centrifugal fan is installed on the supply air side and another at the exhaust air outlet. The window heat recovery system works in all four seasons, for example, in winter, its purpose is to recover heat from exhausted air to the supplied fresh air, and in summer, the exhausted air cools the supplied air.

\subsection{Numerical modelling}

In this study, a window heat recovery system made of two layers $\left(N_{P}=2\right)$, each one containing three heat pipes connected in serial $\left(N_{S}=3\right)$ is considered as reference configuration (Fig. 2). Heat pipes can be defined as passive thermal devices designed to provide effective transport of thermal energy. Nevertheless, modelling the physical phenomena that occur in heat pipes is complex. Nevertheless, the focus of this work is the development of a numerical model able to predict with appropriate accuracy the global performance of window heat recovery systems made of heat pipes. Therefore, for modelling purposes, it is reasonable to consider the heat pipe as a pseudo solid material with a high effective value of thermal conductivity (Stark et al., 2016). 


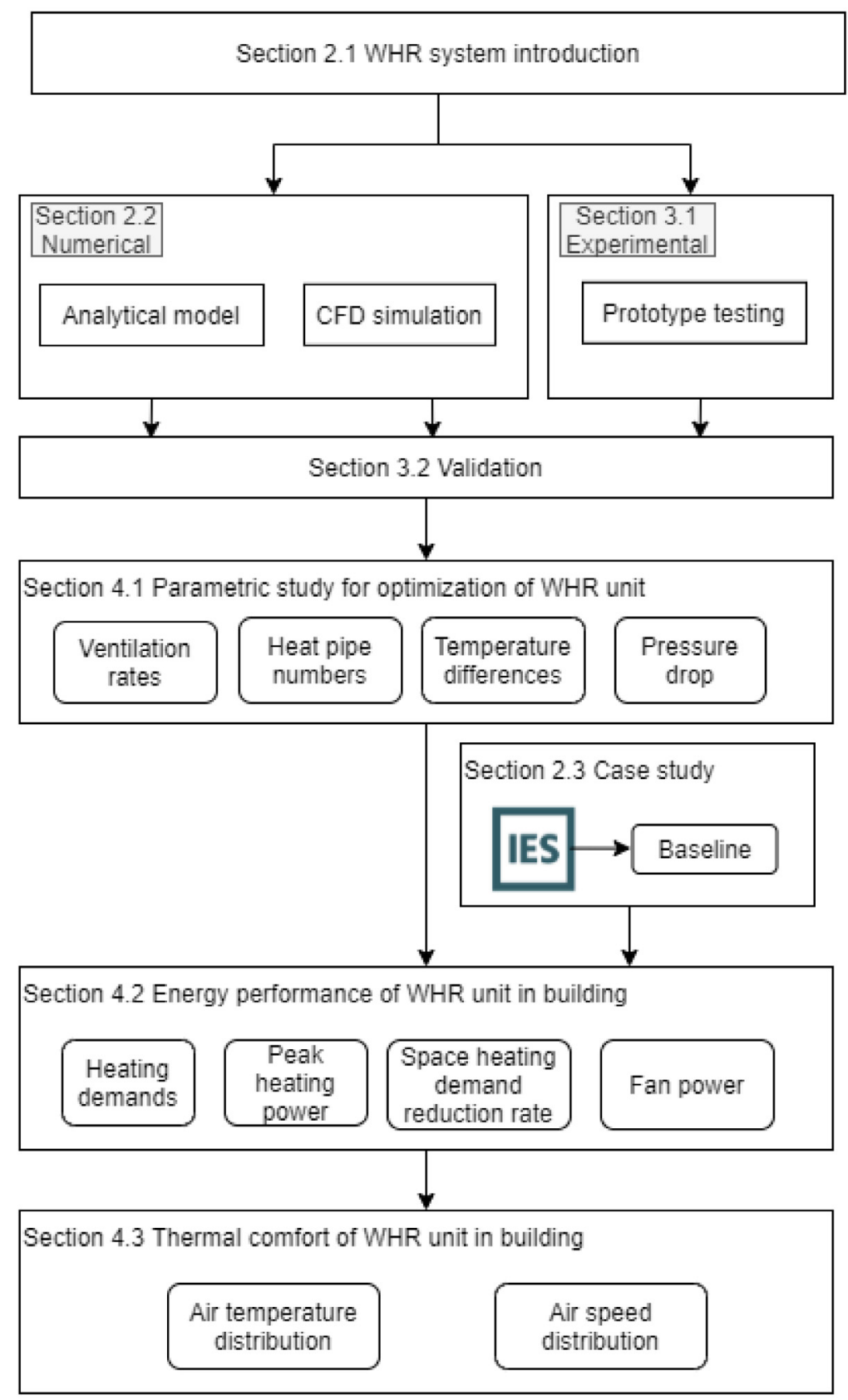

Fig. 1. The research methodology flowchart.

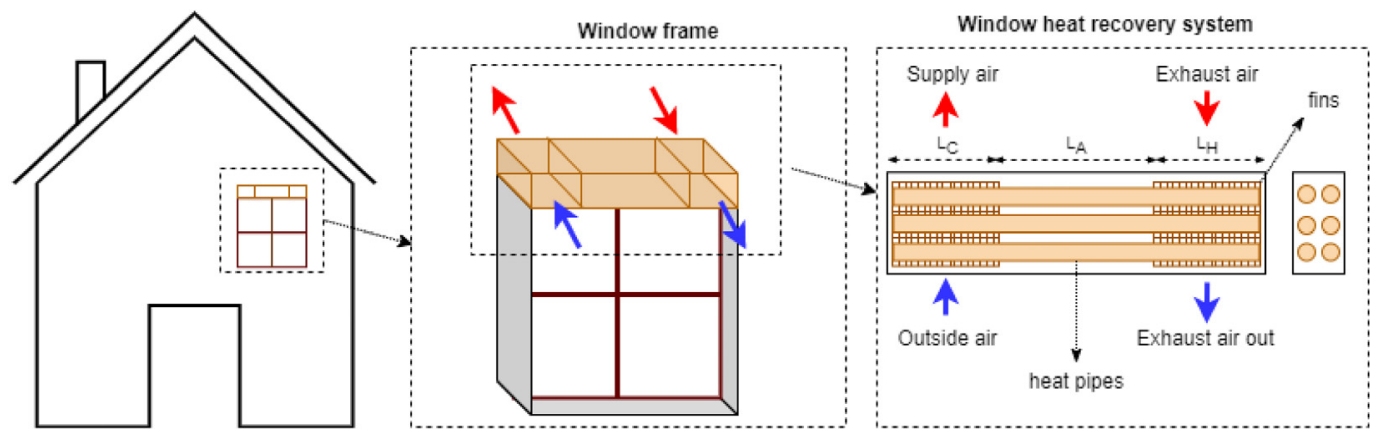

Fig. 2. Window heat recovery system integrated with building (Winter example).

Circular fins are used to improve heat transfer on the hot and cold sides of the heat recovery system. Fig. 3 presents the total thermal resistance network for a single layer of three heat pipes and the thermal resistances for a single heat pipe. 


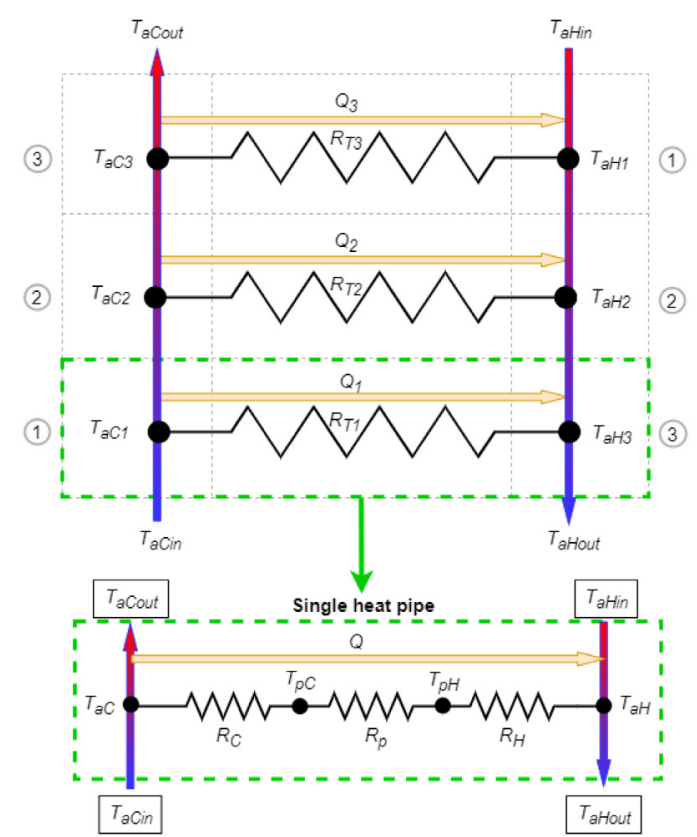

Fig. 3. Thermal resistance network between heat pipes and air in cold and hot sides.

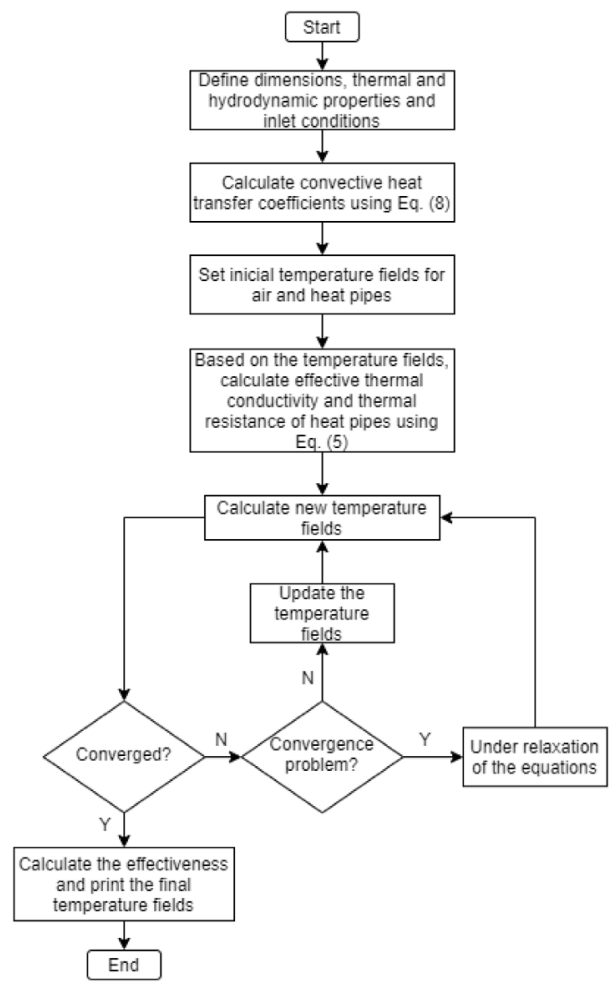

Fig. 4. The flowchart of the solution method.

In this approach, the window heat recovery system can be modelled as a counter flow heat exchanger. It is assumed that air flowing through the system is divided into equal parts for the number of layers of heat pipes without thermal losses at steady-state conditions. Then, Eqs. (1)-(2) can be used to describe a single heat pipe:

$Q=\frac{T_{p C}-T_{a C}}{R_{C}}=\frac{T_{p H}-T_{p C}}{R_{p}}=\frac{T_{a H}-T_{p H}}{R_{H}}=\frac{T_{a H}-T_{a C}}{R_{T}}$
$Q=\dot{m}_{C} C_{p}\left(T_{a \text { Cout }}-T_{a \text { Cin }}\right)=\dot{m}_{H} C_{p}\left(T_{a H i n}-T_{a H o u t}\right)$

where $Q$ is the heat flow through the heat pipe from hot to the cold side, $T_{p C}$ and $T_{p H}$ are the mean temperature of heat pipes in the cold and hot side, $T_{a c}$ and $T_{a H}$ are the mean air temperature on the cold and hot side, $R_{C}$ and $R_{H}$ are the thermal resistance (convective), $R_{p}$ is the conductance thermal resistance of heat pipe, $\dot{m}_{C}$ and $\dot{m}_{H}$ are the air mass flow rate, $C_{p}$ is the specific heat capacity of air, and $T_{a \text { Cout }}, T_{a \text { Cin }}, T_{a H o u t}$ and $T_{a H i n}$ are, respectively, inlet and outlet temperature of the air in cold and hot sides. The total thermal resistance $R_{T}$, convective and conductance thermal resistances are calculated using:

$R_{T}=R_{C}+R_{p}+R_{H}$

$R_{C}=\frac{1}{h A_{C}}$

$R_{p}=\frac{L_{e f f}}{A_{p} k_{e f f}}$

$R_{H}=\frac{1}{h A_{H}}$

where $h$ is the convective heat transfer coefficient on the cold and hot side (it is considered the same value for both sides), $A_{C}$ and $A_{H}$ are total heat transfer areas, which depend on the number of fins $N_{f}$ in each side, the distance between fins $d_{b t f}$, diameter $D_{f}$ and thickness $f$ th (it is considered both sides with the same number of fins). The parameters $L_{\text {eff }}$ and $k_{\text {eff }}$ are the effective length and thermal conductivity of heat pipe, respectively, and $A_{p}$ is the cross-section area of the heat pipe $\left(A_{p}=\pi\left(D_{p} / 2\right)^{2}\right)$. The effective length is calculated using (Zhu et al., 2020):

$L_{\text {eff }}=L_{A}+\frac{L_{C}+L_{H}}{2}$

in which $L_{A}$ is the adiabatic length and $L_{C}$ and $L_{H}$ are the length of the cold and hot sides, respectively (see Fig. 2). The effective thermal conductivity is estimated according to the experimental work described in Section 3.1.1.

\subsubsection{Convective heat transfer coefficient}

For convective heat transfer coefficient in cold and hot sides, the following correlation for the average Nusselt number $\overline{\mathrm{Nu}}$ from the work of Romero-Méndez et al. (2000) is used with some modifications:

$\overline{N u}=\frac{h D_{p}}{k_{a}}=F \operatorname{RePr} \frac{W S}{A_{f} / D_{p}^{2}+\pi S}\left[1-\exp \left(-\frac{1.32 \operatorname{Pr}^{4 / 3} W^{1 / 2}}{\operatorname{Re}^{1 / 2} S}\right)\right]$

where $k_{a}$ is the thermal conductivity of air, $F$ is a calibration factor, Re is the Reynolds number, $\operatorname{Pr}$ is the Prandtl number, $W=D_{f} / D_{p}$ is the nondimensional diameter of the fins, $S=$ $d_{b t f} / D_{p}$ is the nondimensional distance between fins, $A_{f}$ is the total surface area of a single fin (the circular and annular surfaces area), where $A_{f} / D_{p}^{2}$ is the nondimensional fin surface area. The Reynold number is calculated using:

$\operatorname{Re}=\frac{\rho V D_{p}}{\mu}$

in which $\rho, \mu$ and $V$ are the air density, dynamic viscosity, and velocity, respectively. The velocity of air is obtained from mass flow rate $\left(\dot{m}_{C}\right.$ and $\left.\dot{m}_{H}\right)$, density, and the total cross-section area of void space between fins.

The correlation from Eq. (8) (excluding the $F$ factor) is originally obtained by analysing (CFD and experimental) a heat pipe with a single pair of rectangular fins (Romero-Méndez et al., 


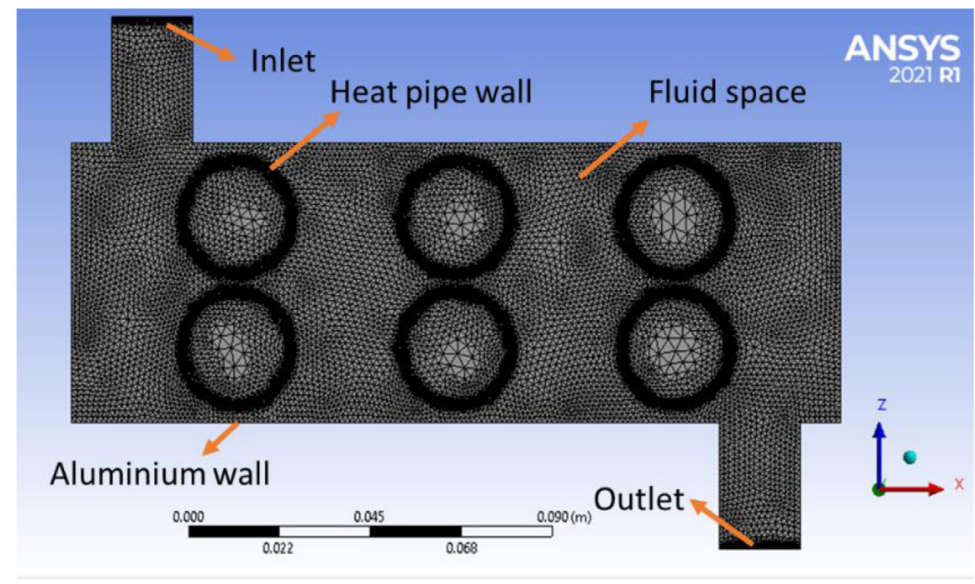

(a)

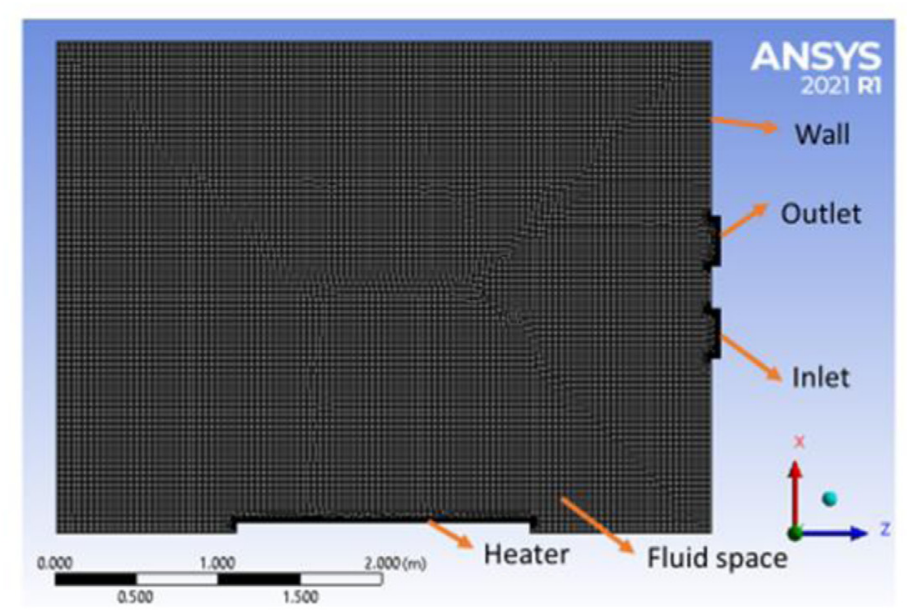

(b)

Fig. 5. (a) Computational mesh of the heat pipes. (b) Computational mesh of the small room.

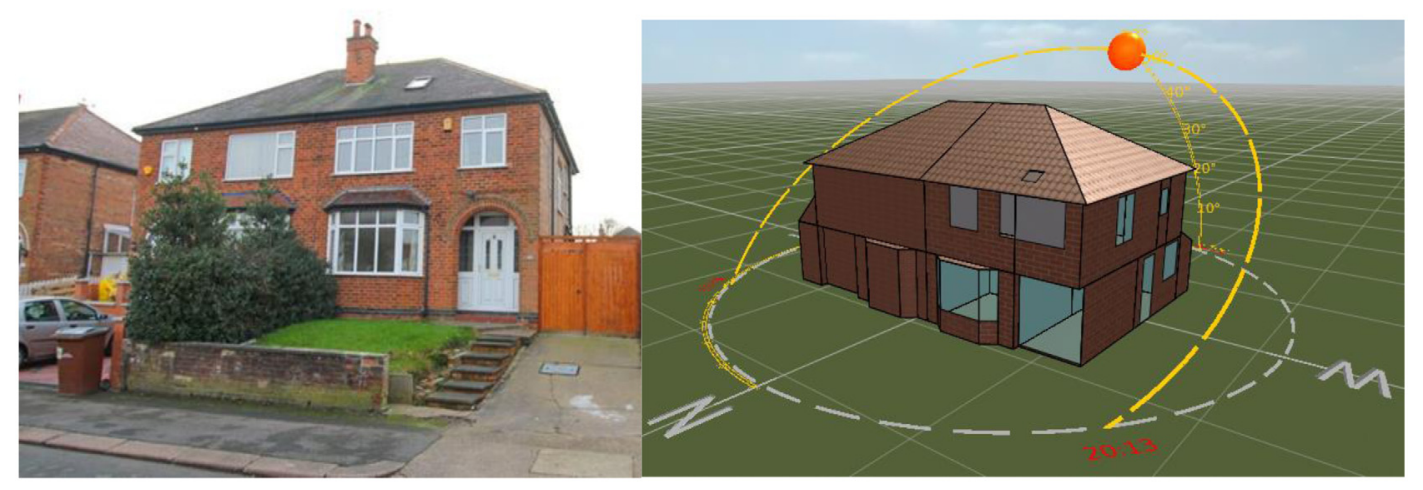

(a) On-site semi-detached house

(b) Model establishment in IESVE

Fig. 6. Physical model of the semi-detached house (right half building) in Nottingham, UK.

2000). According to Stark and Bergman (2017), this correlation underpredicts the convective heat transfer coefficient. Furthermore, the correlation was obtained considering only a single pair of fins, which significantly decrease its accuracy to predict the Nusselt number when a high number of fins is used. For this reason, a calibration factor $F$ is included in the correlation and then its values was adjusted in order to minimise difference between numerical and experimental presented in Section 3.1.1.

\subsubsection{Solution method, performance and parameters}

The equations were solved using GNU Octave software through an iterative process. The procedure is presented in the flow chart of Fig. 4. 

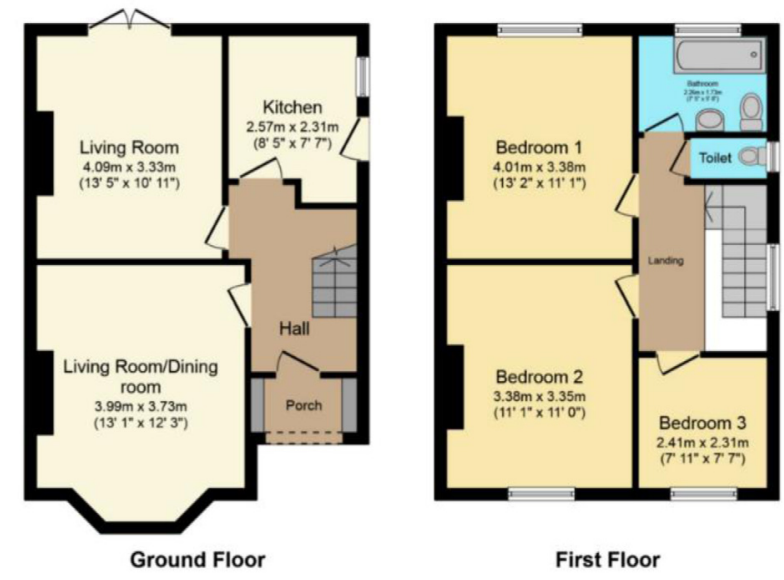

Fig. 7. Building floor plan.

Table 2

Geometric parameters of the window heat recovery system.

\begin{tabular}{ll}
\hline Parameter & Value \\
\hline$L_{C}=L_{H}(\mathrm{~cm})$ & 50 \\
$L_{A}(\mathrm{~cm})$ & 10 \\
$N_{f}$ & 134 \\
$D_{p}(\mathrm{~cm})$ & 2 \\
$D_{f}(\mathrm{~cm})$ & 4 \\
$f_{\text {th }}(\mathrm{mm})$ & 1.5 \\
$d_{b t f}(\mathrm{~mm})$ & 2.25 \\
$N_{P}$ & 2 \\
$N_{S}$ & 3 \\
\hline
\end{tabular}

For the heat pipes connected in serial (single layer), we have used finite volume method (FVM), in which a single heat pipe is considered as the control volume. For each control volume, Eqs. (1) and (2) are solved to obtain the temperature fields. The connection between different control volumes is made by considering that outlet conditions of one heat pipe are the inlet conditions of the next heat pipe. When the governing equations are solved for each control volume, the effectiveness of the window heat recovery is calculated using the following equation:

$$
\begin{gathered}
\varepsilon=\frac{\dot{m}_{C} C_{p}\left(T_{a C o u t}-T_{a C i n}\right)}{\min \left(\dot{m}_{C} C_{p} ; \dot{m}_{H} C_{p}\right)\left(T_{a H i n}-T_{a C i n}\right)} \\
=\frac{\dot{m}_{H} C_{p}\left(T_{a H i n}-T_{a H o u t}\right)}{\min \left(\dot{m}_{C} C_{p} ; \dot{m}_{H} C_{p}\right)\left(T_{a H i n}-T_{a C i n}\right)}
\end{gathered}
$$

where $\min \left(\dot{m}_{C} C_{p} ; \dot{m}_{H} C_{p}\right)$ is the minimum value between the product's mass flow rate and specific heat capacity of the cold and hot sides. In Eq. (10), the inlet and outlet temperatures are for the first and last heat pipes (see Fig. 3). The geometric parameters of the reference configuration of the window heat recovery used in the simulations are presented in Table 2. The thermal and hydrodynamic properties of air are considered constant for a temperature of $25^{\circ} \mathrm{C}$.

\subsubsection{CFD modelling method}

The CFD code ANSYS 2021 R1 was used in this study to validate the accuracy of heat pipe effectiveness along with simulating the air and velocity distribution in the small room connected to the heat pipe model. The simulation of the heat pipe and the attached room was considered the steady state with a twodimensional computational model where the CFD code used the Finite Volume Method (FVM) with the Semi Implicit Method for Pressure Linked Equations (SIMPLE) velocity-pressure coupling algorithm. The turbulent element of the airflow was modelled using the Realisable $\mathrm{k}-\varepsilon$ turbulence model with enhanced wall functions to get further improved prediction for flows involving rotation and boundary layers under strong adverse pressure gradients inside the heat pipe model (Seyyedvalilu, 2021; Andersson et al., 2011; Calautit and Hughes, 2014a). The k- $\varepsilon$ model for turbulence is the most common to simulate the mean flow characteristics for turbulent flow conditions. However, the Realisable $\mathrm{k}-\varepsilon$ model differs from the standard $\mathrm{k}-\varepsilon$ model in that the $\varepsilon$ of the former model is derived from an exact equation for the transport of the mean-square vorticity fluctuation, resulting in improved predictions for the mean flow of complex structures (Calautit and Hughes, 2014a). Moreover, the enhanced wall treatment is a blended wall model or wall function. It blends the separate models in the two-layer approach by using a damping function to make the transition smoother (Brozovsky et al., 2021). Meanwhile, Second-order upwind schemes were adopted for the calculation. Before the simulation process, the under-relaxation factors for pressure, momentum, $\mathrm{k}$ and $\varepsilon$ were set to $0.2,0.25$, 0.25 and 0.25 for both heat pipe and room models, respectively. Convergence steps were set to 10000 , where the convergence was monitored, and iterations were ended when all residuals showed no further declinations with the increasing iterations. The governing equations were fully introduced in the ANSYS FLUENT Guide (ANSYS, 2013). The heat pipe and the exterior wall surfaces are made of copper and aluminium, respectively, assuming that all the surfaces are stationary walls. The boundary condition assumes that the velocity reduces to 0 when reaching the aluminium wall surface with the Intensity and Viscosity Ratio specification method used in the turbulence model. The turbulent intensity and turbulent viscosity ratio remain at $10 \%$ during the simulation process.

The geometry of heat pipe and room models was created using the SpaceClaim (FLUENT pre-processor) in the ANSYS 2021 Workbench. According to the configuration of the heat pipe and room models described in Section 2.2, the established geometry was imported into ANSYS mesh processor where the fluid surfaces areas were not extracted from the model since both the conduction and convection models were investigated in this study. The constructed mesh was used to discretise the surface of the computational domains. All triangles method was used for heat pipe model to acquire the best split near heat pipe sections whereas Quadrilateral method for the small room model. The size of mesh elements was improved smoothly to solve those sections with high gradient mesh to require more accurate results of the velocity and temperature fields near the velocity inlet, pressure outlet, and heat pipe walls (Calautit and Hughes, 2014b; Calautit et al., 2014). Furthermore, level 3 refinements were applied in these areas as well. The mesh element size of the heat pipe and room models for surfaces and edges were $10 \mathrm{~mm}$ and $5 \mathrm{~mm}$, with the total element number of 348340 and 330870 , respectively. The modelled meshes of the heat pipe and small room models using ANSYS Mesh are shown in Fig. 5(a) and (b).

\subsection{Case study}

In this research, a semi-detached 2-bedroom house with a total floor area of $85 \mathrm{~m}^{2}$ is selected as the case study to investigate the impact of window heat recovery (WHR) ventilation on the building post-retrofit energy performance and indoor air temperature, velocity distributions. The energy performance is evaluated by the heating demand reduction rate and peak heating power considering ventilation rates varied between $10-60 \mathrm{~m}^{3} / \mathrm{h}$ for each room, with a physical model established in IES VE building energy simulation software, as depicted in Fig. 6. The living room on the ground floor is selected to investigate the indoor air temperature, velocity distributions with installing the WHR system, including 


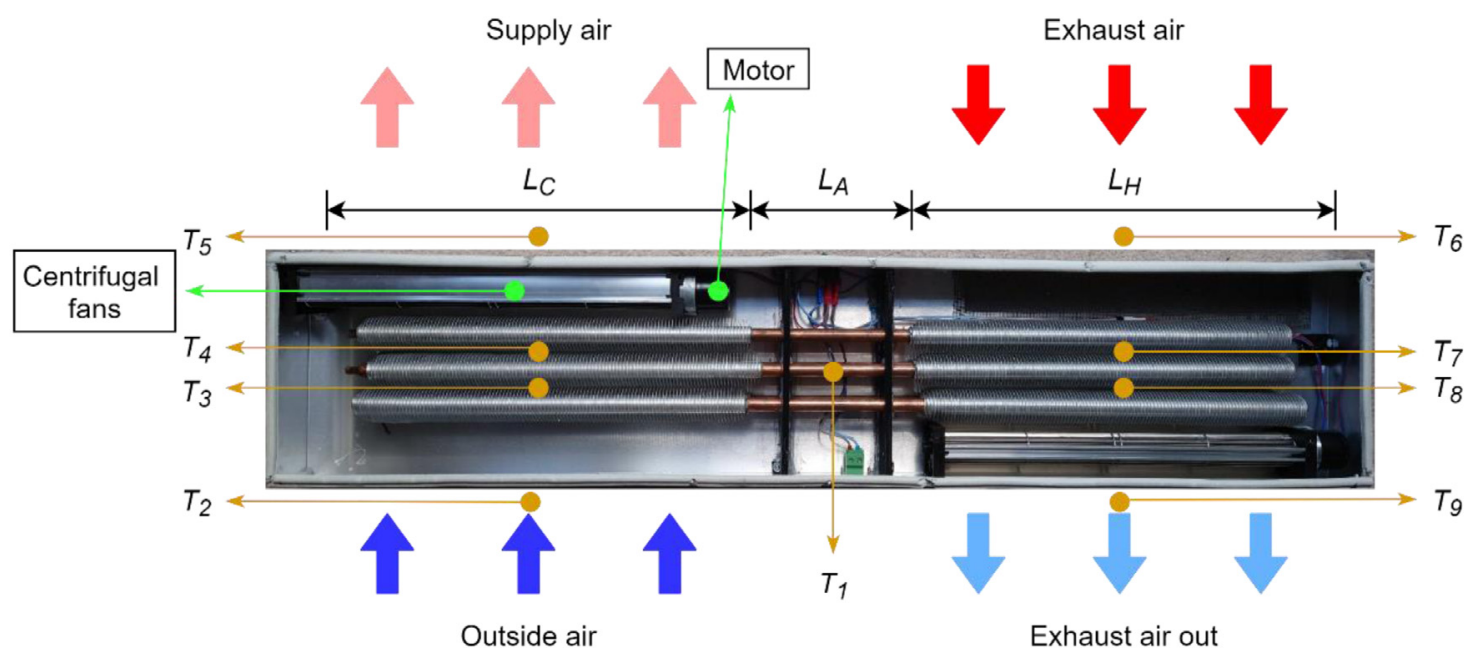

Fig. 8. Window heat recovery prototype used in the experiments.

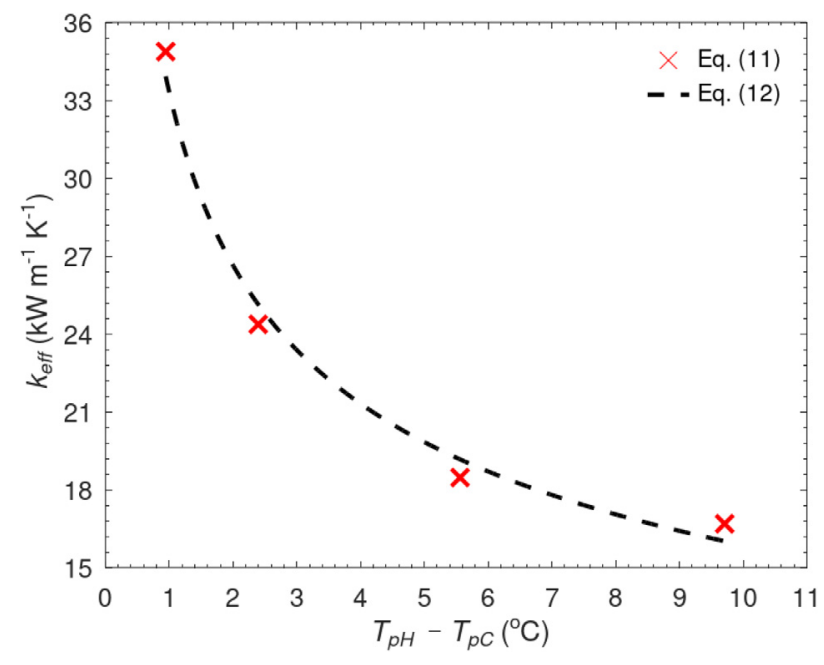

Fig. 9. Effective thermal conductivity for the temperature differences.

air temperature and velocity distribution and summer overheating mitigation issues, with the floor plan and living room location shown in Fig. 7.

The building is a solid wall constructed in 1948 with a wall U-value of $2.1 \mathrm{~W} / \mathrm{m}^{2} \mathrm{~K}$. All windows applied double glazing with a U-value of $2.5 \mathrm{~W} / \mathrm{m}^{2} \mathrm{~K}$, and pitched roofs are insulated by rigid polyisocyanurate (PIR) insulation with a U-value of $0.22 \mathrm{~W} / \mathrm{m}^{2}$ $\mathrm{K}$. Besides, the ground floor is also solid-wall constructed with a U-value of $0.85 \mathrm{~W} / \mathrm{m}^{2} \mathrm{~K}$, and the attic floor is insulated with rock wool with a total U-value of $0.90 \mathrm{~W} / \mathrm{m}^{2} \mathrm{~K}$. The airtightness for the main building and the loft is tested with $2.69 \mathrm{ACH}$ and 4.18 ACH under a pressure difference of $50 \mathrm{~Pa}$. The high-intensity solar radiation periods are between May and August, while lowintensity periods are for the rest of the months. The highest and lowest ambient temperatures are $33.6{ }^{\circ} \mathrm{C}$ and $-2.0^{\circ} \mathrm{C}$.

The space heating is powered only by natural gas, driven by combi-boilers with a seasonal heating energy efficiency of $94 \%$. Moreover, the space heating set temperature for the whole house is $19{ }^{\circ} \mathrm{C}(08: 00-17: 00 \mathrm{~h})$ and $22{ }^{\circ} \mathrm{C}(00: 00-08: 00 \mathrm{~h}, 17: 00-$ 24:00 h), respectively. No cooling system was installed according to the local weather data.

\section{Experimental and validation}

\subsection{Experimental}

The window heat recovery prototype presented in Fig. 8 was tested under different conditions, where the ventilation rates are regulated with 6-levels by the centrifugal fan and its controllable motor from 10 to $60 \mathrm{~m}^{3} / \mathrm{h}$. The temperature was recorded in different locations, as identified in Fig. 8 ( $T_{1}$ to $T_{9}$ are temperature sensors), and then the average temperature on the two sides of the pipes and the average heat flux are calculated. Besides, air pressure differences between inlet and outlet of supply and exhaust air side are measured, with varied air velocity from $10-60 \mathrm{~m}^{3} / \mathrm{h}$.

\subsubsection{Determination of effective thermal conductivity}

For the determination of effective thermal conductivity, the following relation resulted from the combination of Eqs. (1) and (5) is used:

$k_{e f f}=\frac{Q_{a v} L_{e f f}}{A_{p}\left(T_{p H}-T_{p C}\right)}$

where $Q_{a v}$ is the mean heat flowing through a single heat pipe and $T_{p H}$ and $T_{p c}$ are, respectively, the average heat pipe hot side temperature and cold side temperature. The experiments are conducted for $\dot{m}_{C}=\dot{m}_{H}$ This means that the temperature profiles from inlet to outlet on each side can be considered approximately linear. To simplify the approach to estimating the effective thermal conductivity without compromising the accuracy, it is assumed that the total heat flux is divided into equal parts for all heat pipes $Q_{a v}=Q_{T} /\left(N_{P} N_{S}\right)$. The total heat flux $Q_{T}$ is calculated using Eq. (2), the temperature recorded in locations $T_{2}, T_{5}, T_{6}$ and $T_{9}$ and the mass flow rate. The length $L_{e f f}$ is calculated from Eq. (7), and the temperature difference $T_{p H}-T_{p C}$ is calculated using the average temperature difference between $T_{2}$ to $T_{5}$ and $T_{9}$ to $T_{6}$. The inlet temperature of the cold and hot sides are changed according to Table 3 , and the mass flow rate is fixed in $\dot{m}_{C}=\dot{m}_{H}=69.1 \mathrm{~m}^{3} / \mathrm{h}$. Fig. 9 presents the obtained effective thermal conductivity for the temperature differences between the hot and cold sides.

To obtain a correlation to be used in the numerical model, the data from Fig. 9 is fitted using a power-law curve, where the following equation with $R^{2}=0.985$ is obtained:

$k_{\text {eff }}=33298.8\left(T_{p H}-T_{p C}\right)^{-0.322}$ 


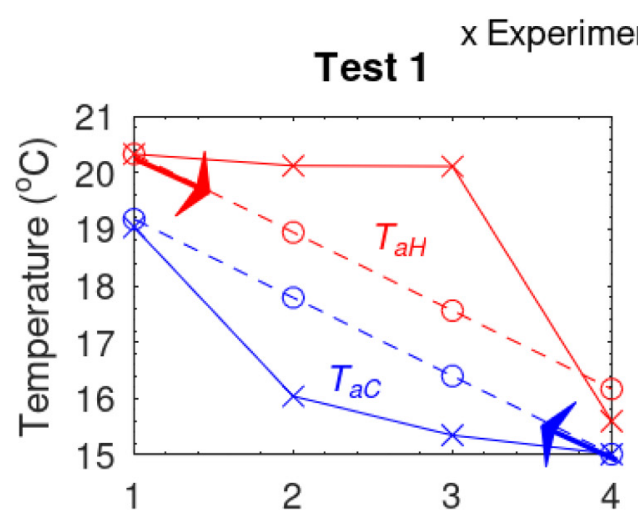

Test 3

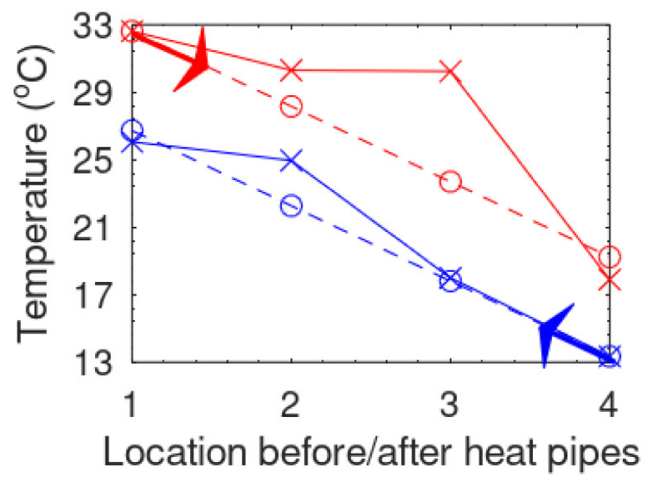

- - o Numerical Test 2

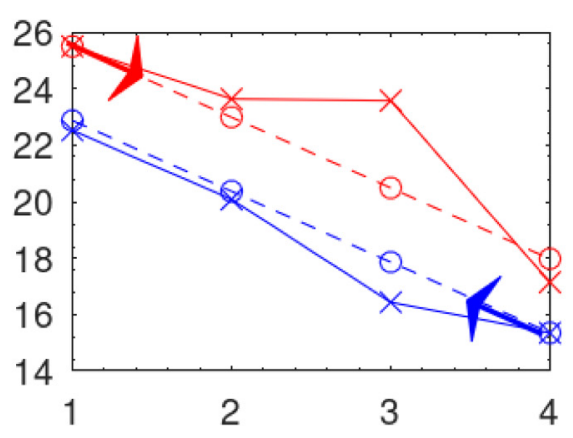

Test 4

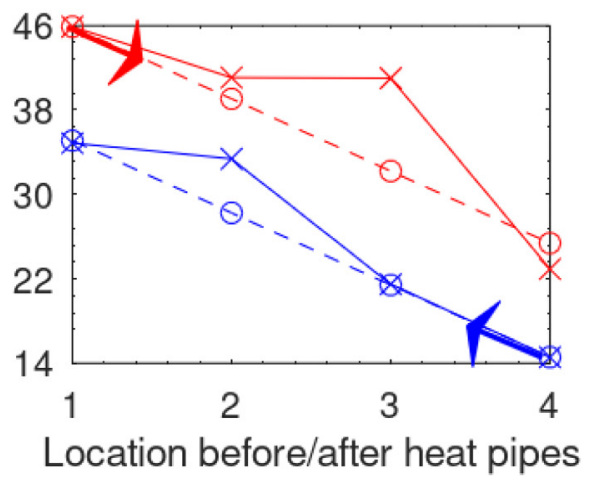

Fig. 10. Comparison between experimental and numerical results for different test conditions.

\subsection{Validation}

\subsubsection{Analytical formulation}

After determining effective thermal conductivity, the calibration factor $F$, introduced in Eq. (8), was adjusted to minimise the difference between numerical and experiments, where a value of $F=25$ was found. This value and the proposed effective thermal conductivity correlation were then used in the simulations. The temperature distribution before and after each heat pipe measured during the experiments and obtained from the numerical model for four different test conditions are presented in Fig. 10.

There are some minor differences between measurements and numerical results, but it can be considered that the numerical model can predict reasonably the outlet temperature of air (the most important) on each side. The main differences are in the temperature recorded in the middle heat pipes (locations 2 and 3 ). This is mainly due to the difficulty on inserting the temperature sensors (thermocouples) exactly in between those heat pipes, where the thermocouples might be affected by the heat pipe wall surface. However, the impact of heat pipe wall surface on the thermocouples will be mitigated due to the adequate space between them, which indicates the agreement of the total temperature differences of simulation and experiments. The comparison between outlet temperature for the four test conditions obtained from experimental (Exp.) and numerical (Num.) are presented in Table 3.

According to the results presented in Table 3, the maximum difference between measured and modelled outlet temperature is always on the hot side, which are $3.8 \%, 5.3 \%, 7.3 \%$ and $10.9 \%$, respectively, for tests $1,2,3$ and 4 . This difference increase when we increase the temperature range, which can be explained due to thermal losses not accounted for in the numerical model. According to this result, it is considered that the model can be
Table 3

Comparison between measured and modelled outlet temperature.

\begin{tabular}{|c|c|c|c|c|c|c|c|c|}
\hline & \multicolumn{2}{|c|}{ Test 1} & \multicolumn{2}{|c|}{ Test 2} & \multicolumn{2}{|c|}{ Test 3} & \multicolumn{2}{|c|}{ Test 4} \\
\hline & Exp. & Num. & Exp. & Num. & Exp. & Num. & Exp. & Num. \\
\hline$T_{a \operatorname{Cin}}\left({ }^{\circ} \mathrm{C}\right)$ & \multicolumn{2}{|c|}{15} & \multicolumn{2}{|c|}{15.3} & \multicolumn{2}{|c|}{13.4} & \multicolumn{2}{|c|}{14.6} \\
\hline $\boldsymbol{T}_{\text {aCout }}\left({ }^{\circ} \mathbf{C}\right)$ & 19.0 & 19.2 & 22.5 & 22.9 & 26.0 & 26.7 & 34.9 & 35.1 \\
\hline$T_{a \operatorname{Hin}}\left({ }^{\circ} \mathrm{C}\right)$ & \multicolumn{2}{|c|}{20.4} & \multicolumn{2}{|c|}{25.5} & \multicolumn{2}{|c|}{32.6} & \multicolumn{2}{|c|}{45.9} \\
\hline $\boldsymbol{T}_{\text {aHout }}\left({ }^{\circ} \mathbf{C}\right)$ & 15.6 & 16.2 & 17.1 & 18.0 & 17.9 & 19.2 & 22.9 & 25.4 \\
\hline
\end{tabular}

used to study the performance of the window heat recovery system for other conditions.

\subsubsection{CFD validation}

Apart from the analytical formulation, the CFD simulation of the hot and cold side temperature was conducted to compare with the numerical results. Fig. 11(a) and (b) show the temperature and velocity distribution profile of the model with the cold inlet temperature of $15{ }^{\circ} \mathrm{C}$ and inlet velocity of $0.93 \mathrm{~m} / \mathrm{s}$. The comparison between hot and cold outlet temperature for the four tests conditions obtained in CFD simulation (CFD) and numerical (Num.) are presented in Table 4. Minor differences between the two methods exist, however, the discrepancies of hot side outlet temperature for CFD simulation and numerical method gradually increase with the more considerable temperature differences, which are $2.4 \%, 2.6 \%, 2.8 \%$ and $3.2 \%$ for tests $1,2,3$ and 4 . The reason may be ascribed to that (1) The iteration has not fully converged; (2) The representation of the governing flow equations and other physical models as algebraic expressions in a discrete domain of space and time; (3) The meshing grid has not been precisely refined; (4) Little computing values per cell and resulting interpolation errors. 

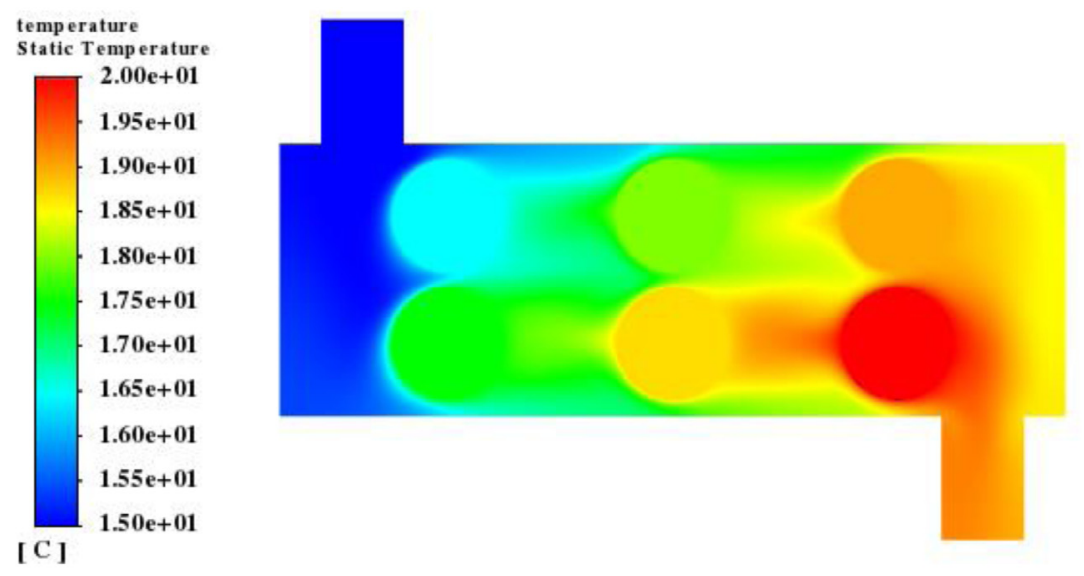

(a)
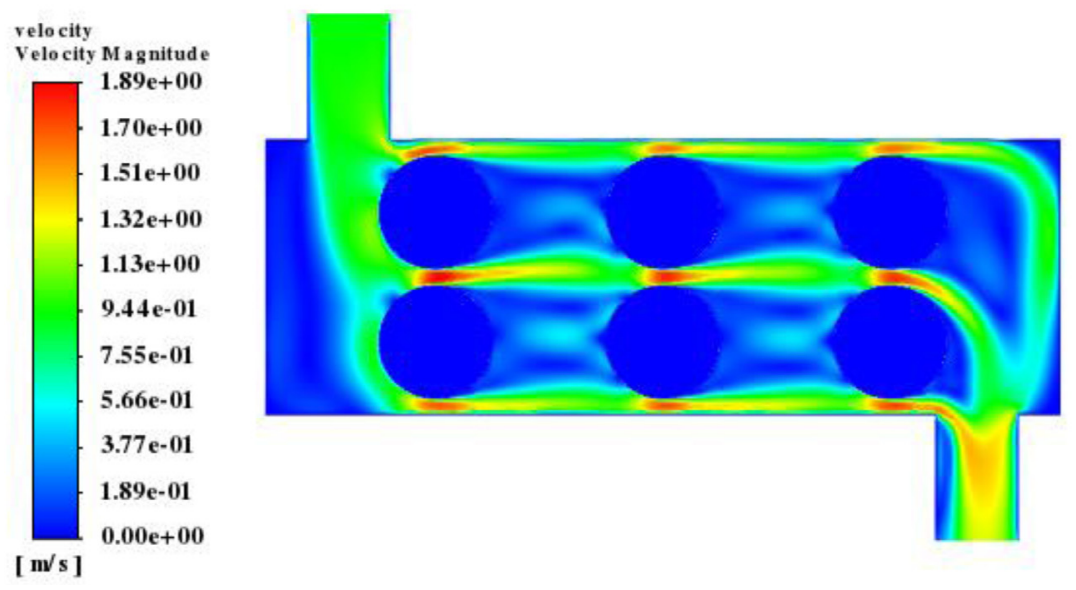

(b)

Fig. 11. CFD simulation results with an inlet temperature of $15{ }^{\circ} \mathrm{C}$ and inlet velocity of $0.93 \mathrm{~m} / \mathrm{s}$ : (a) Temperature and (b) velocity magnitude.

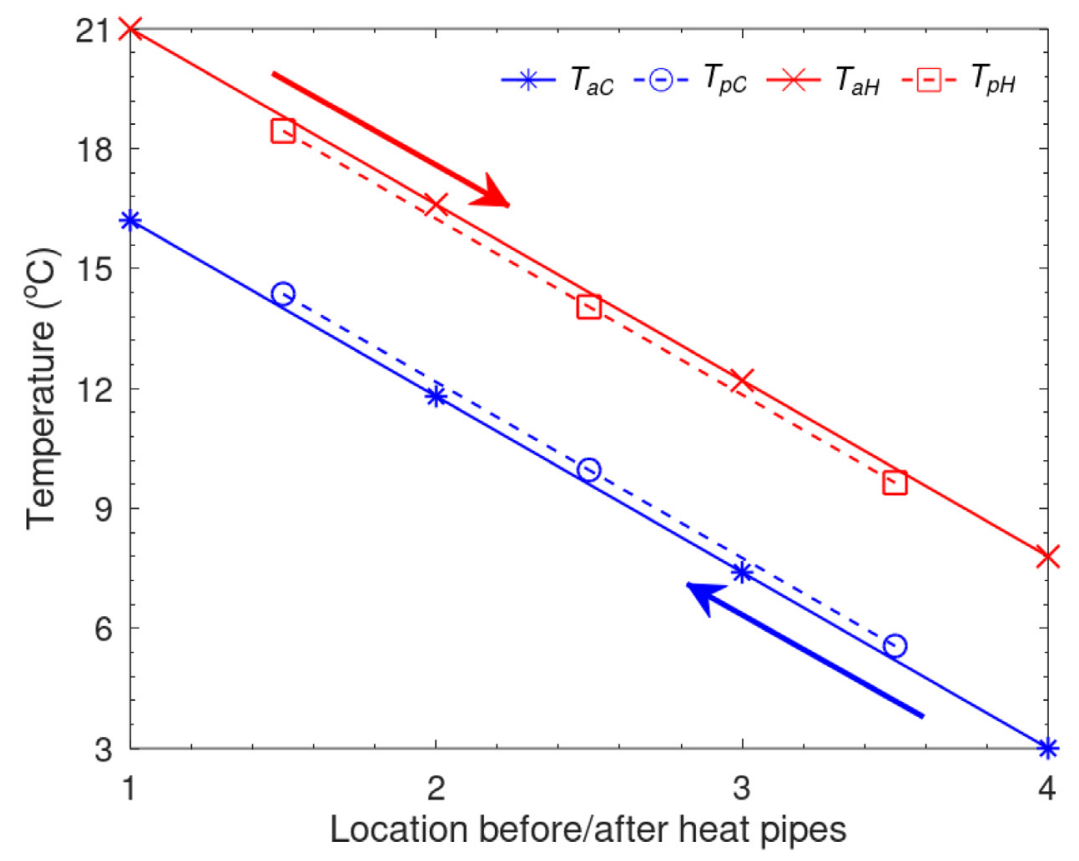

Fig. 12. Temperature profile in air and heat pipe along the flow direction of the window heat recovery system. 


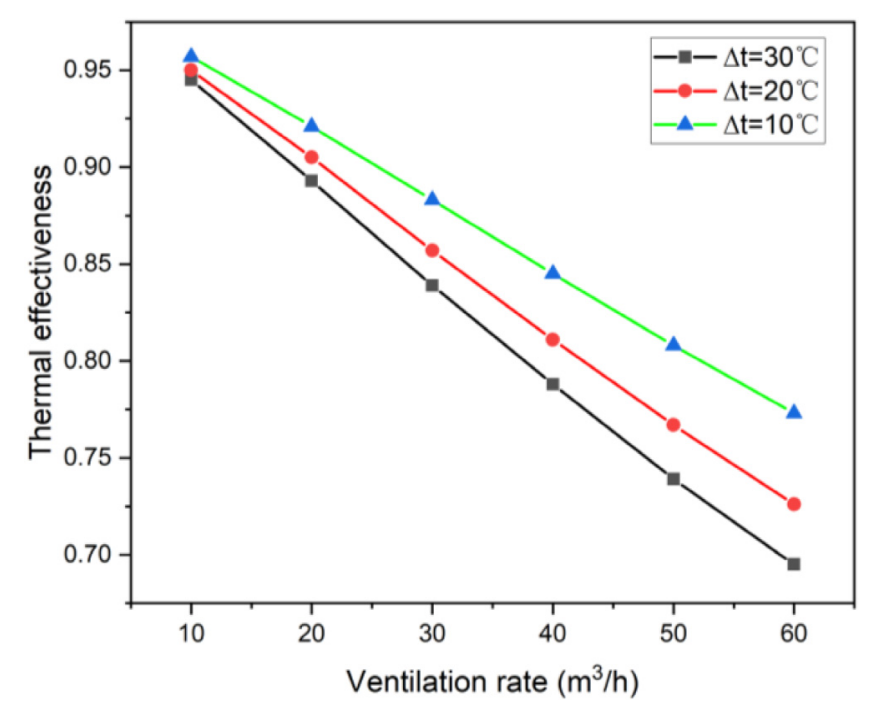

Fig. 13. Impact of maximum temperature difference on the thermal effectiveness with ventilation rate varied between 10 to $60 \mathrm{~m}^{3} / \mathrm{h}$.

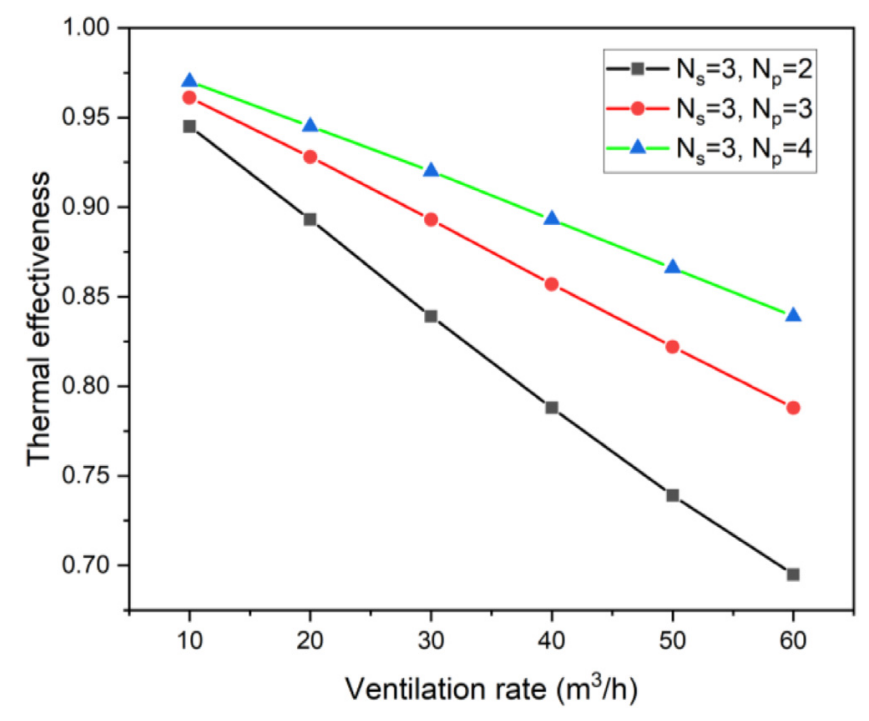

Fig. 14. Impact of heat pipe numbers on the thermal effectiveness with ventilation rate varied between 10 to $60 \mathrm{~m}^{3} / \mathrm{h}$.

Table 4

Comparison between CFD simulation and numerical outlet temperatures.

\begin{tabular}{|c|c|c|c|c|c|c|c|c|}
\hline & \multicolumn{2}{|c|}{ Test 1} & \multicolumn{2}{|c|}{ Test 2} & \multicolumn{2}{|c|}{ Test 3} & \multicolumn{2}{|c|}{ Test 4} \\
\hline & $\overline{C F D}$ & Num. & CFD. & Num. & CFD. & Num. & CFD. & Num. \\
\hline$T_{a \text { Cin }}\left({ }^{\circ} \mathrm{C}\right)$ & \multicolumn{2}{|c|}{15} & \multicolumn{2}{|c|}{15.3} & \multicolumn{2}{|c|}{13.4} & \multicolumn{2}{|c|}{14.6} \\
\hline$T_{\text {aCout }}\left({ }^{\circ} \mathrm{C}\right)$ & 19.1 & 19.2 & 22.5 & 22.9 & 26.1 & 26.7 & 35.2 & 35.1 \\
\hline$T_{a \operatorname{Hin}}\left({ }^{\circ} \mathrm{C}\right)$ & \multicolumn{2}{|c|}{20.4} & \multicolumn{2}{|c|}{25.5} & \multicolumn{2}{|c|}{32.6} & \multicolumn{2}{|c|}{45.9} \\
\hline$T_{\text {aHout }}\left({ }^{\circ} \mathrm{C}\right)$ & 15.8 & 16.2 & 17.5 & 18.0 & 18.7 & 19.2 & 24.6 & 25.4 \\
\hline
\end{tabular}

\section{Results and discussion}

\subsection{Parametric analysis}

After model development and validation, it can be used to study the performance of the window heat recovery system for different conditions. In this section, three parameters upon the WHR thermal effectiveness are analysed with the most significant parameter of ventilation rate. Besides, temperature differences between the cold inlet and the hot outlet also have a noticeable impact on the thermal effectiveness. Furthermore, heat pipe layers have a relatively low influence.

The mass flow rate in the hot and cold side is always considered the same $\left(\dot{m}_{C}=\dot{m}_{H}\right)$ and the geometric reference parameters presented in Table 2 are used. Fig. 12 presents the temperature profile in the air and heat pipe along the flow direction. The profile is linear because of the approaches and the same mass flow rate used on each side.

The inlet temperature, mass flow rate, outlet temperature and effectiveness for the results are presented in Fig. 12, with $T_{a \text { Cin }}=$ $3{ }^{\circ} \mathrm{C}, T_{a H \text { in }}=21{ }^{\circ} \mathrm{C}, \dot{m}_{\mathrm{C}}=\dot{m}_{H}=60 \mathrm{~m}^{3} / \mathrm{h}, T_{a \text { Cout }}=16.2^{\circ} \mathrm{C}$, $T_{\text {aHout }}=7.8{ }^{\circ} \mathrm{C}$, respectively which resulted in the effectiveness of $\varepsilon=73.3 \%$.

Numerical simulation results indicate that the thermal effectiveness slightly drops with the rise of the maximum temperature differences between the cold outside air and hot exhaust air, as shown in Fig. 13. Temperature differences from $10{ }^{\circ} \mathrm{C}, 20^{\circ} \mathrm{C}$ to $30{ }^{\circ} \mathrm{C}$ are investigated with the ventilation rates raised between 10 and $60 \mathrm{~m}^{3} / \mathrm{h}$. It is figured out that the thermal effectiveness is similar in the range of $94.5 \%$ and $95.7 \%$ when a low ventilation rate of $10 \mathrm{~m}^{3} / \mathrm{h}$. However, the thermal effectiveness decreases between $69.5 \%$ and $77.3 \%$ when the ventilation rate rises to $60 \mathrm{~m}^{3} / \mathrm{h}$. Thus, the thermal effectiveness declining rates are calculated as $0.06 \% /{ }^{\circ} \mathrm{C}, 0.14 \% /{ }^{\circ} \mathrm{C}, 0.22 \% /{ }^{\circ} \mathrm{C}, 0.285 \% /{ }^{\circ} \mathrm{C}, 0.345 \% /{ }^{\circ} \mathrm{C}$ and $0.39 \% /{ }^{\circ} \mathrm{C}$ with varied ventilation rates of $10 \mathrm{~m}^{3} / \mathrm{h}, 20 \mathrm{~m}^{3} / \mathrm{h}, 30 \mathrm{~m}^{3} / \mathrm{h}$, $40 \mathrm{~m}^{3} / \mathrm{h}, 50 \mathrm{~m}^{3} / \mathrm{h}$ and $60 \mathrm{~m}^{3} / \mathrm{h}$, respectively. Meanwhile, it is also figured out that the ventilation rates have the most significant impact on the improvement of thermal effectiveness, which reveals that the heat transfer coefficient has noticeable degradation with the rise of the ventilation rate from $10 \mathrm{~m}^{3} / \mathrm{h}$ to $60 \mathrm{~m}^{3} / \mathrm{h}$. The thermal effectiveness is dropped by $18.4 \%, 22.4 \%$ and $25.0 \%$ with the rise of ventilation rate of $50 \mathrm{~m}^{3} / \mathrm{h}$ when the temperature differences are $10{ }^{\circ} \mathrm{C}, 20^{\circ} \mathrm{C}$ and $30^{\circ} \mathrm{C}$, respectively.

It is figured out that the increase of heat pipe numbers has a significant impact on the improvement of thermal effectiveness, as shown in Fig. 14, which reveals that the heat transfer coefficient has a noticeable upgrade when the heat pipe layers increase from $N_{p}=2$ to $N_{p}=3$, with total heat numbers increasing from 6 to 9. Results indicate that the thermal effectiveness is upgraded from $94.5 \%$ to $97.0 \%$ when a low ventilation rate of $10 \mathrm{~m}^{3} / \mathrm{h}$. However, the thermal effectiveness decreased between $69.5 \%$ and $83.9 \%$ when the ventilation rate rises to $60 \mathrm{~m}^{3} / \mathrm{h}$. Thus, the thermal effectiveness decreasing rates are calculated as $1.25 \% /$ layer, $2.6 \% /$ layer, $4.05 \% /$ layer, $5.25 \% /$ layer, $6.35 \% /$ layer and $7.2 \% /$ layer with varied ventilation rates of $10 \mathrm{~m}^{3} / \mathrm{h}, 20 \mathrm{~m}^{3} / \mathrm{h}$, $30 \mathrm{~m}^{3} / \mathrm{h}, 40 \mathrm{~m}^{3} / \mathrm{h}, 50 \mathrm{~m}^{3} / \mathrm{h}$ and $60 \mathrm{~m}^{3} / \mathrm{h}$, respectively.

According to the CFD simulation results, the relative total pressure contour of the WHR system with the cold inlet temperature of $15{ }^{\circ} \mathrm{C}$ and ventilation rate of $10 \mathrm{~m}^{3} / \mathrm{h}$ is shown in Fig. 15. The total pressure drop between the inlet and outlet sides is 4.12 $\mathrm{Pa}$, with the former pressure of $4.69 \mathrm{~Pa}$ and the latter one of $0.57 \mathrm{~Pa}$. Meanwhile, the pressure drop increases with the rise of ventilation rates from $10-60 \mathrm{~m}^{3} / \mathrm{h}$, where the pressure drop is from 4.12 Pa to 77.9 Pa correspondingly, as shown in Fig. 16. Besides, the pressure drop is validated with the experiment where the discrepancies range from $-4.4 \%$ to $9.8 \%$, which is in the reasonable interval. Moreover, the obtained pressure drop from the experiment is larger than that from the CFD simulation when the ventilation rate is relatively low and vice versa. To obtain a correlation that can be used in the calculation of pressure drop under various ventilation rates, the data from Fig. 16 are fitted using an exponential expression, where the following equation Eq. (13) with $R^{2}=0.999$ is obtained:

$\Delta P=0.0931 V_{r}^{1.6417}$

where $\Delta P$ is the total pressure drop between inlet and outlet sides $(\mathrm{Pa})$ and $V_{r}$ is the ventilation rate $\left(\mathrm{m}^{3} / \mathrm{h}\right)$. 

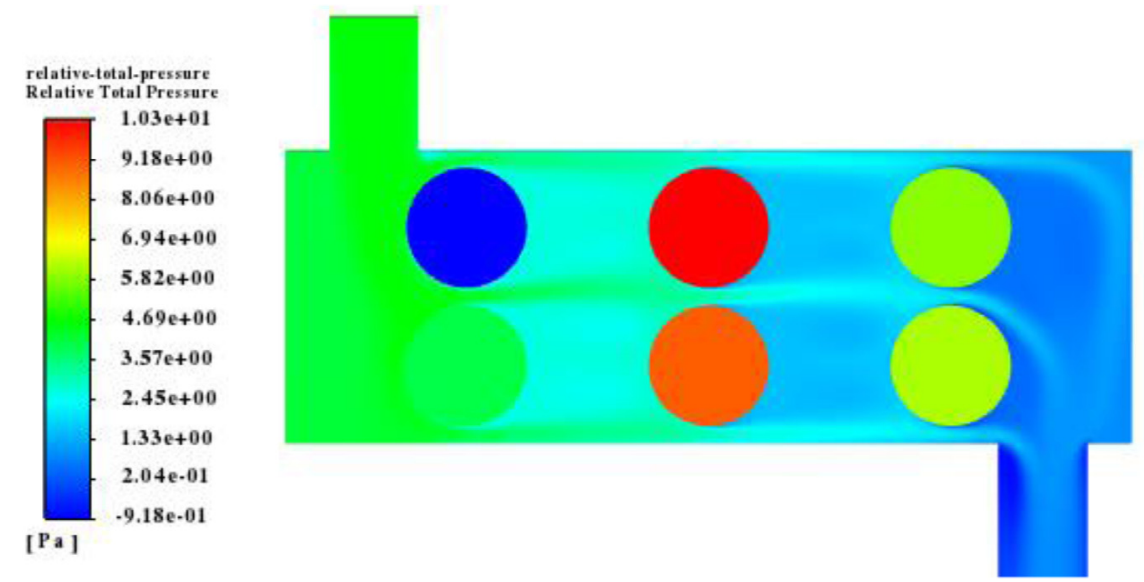

Fig. 15. CFD calculated relative total pressure from inlet to outlet of the WHR system.

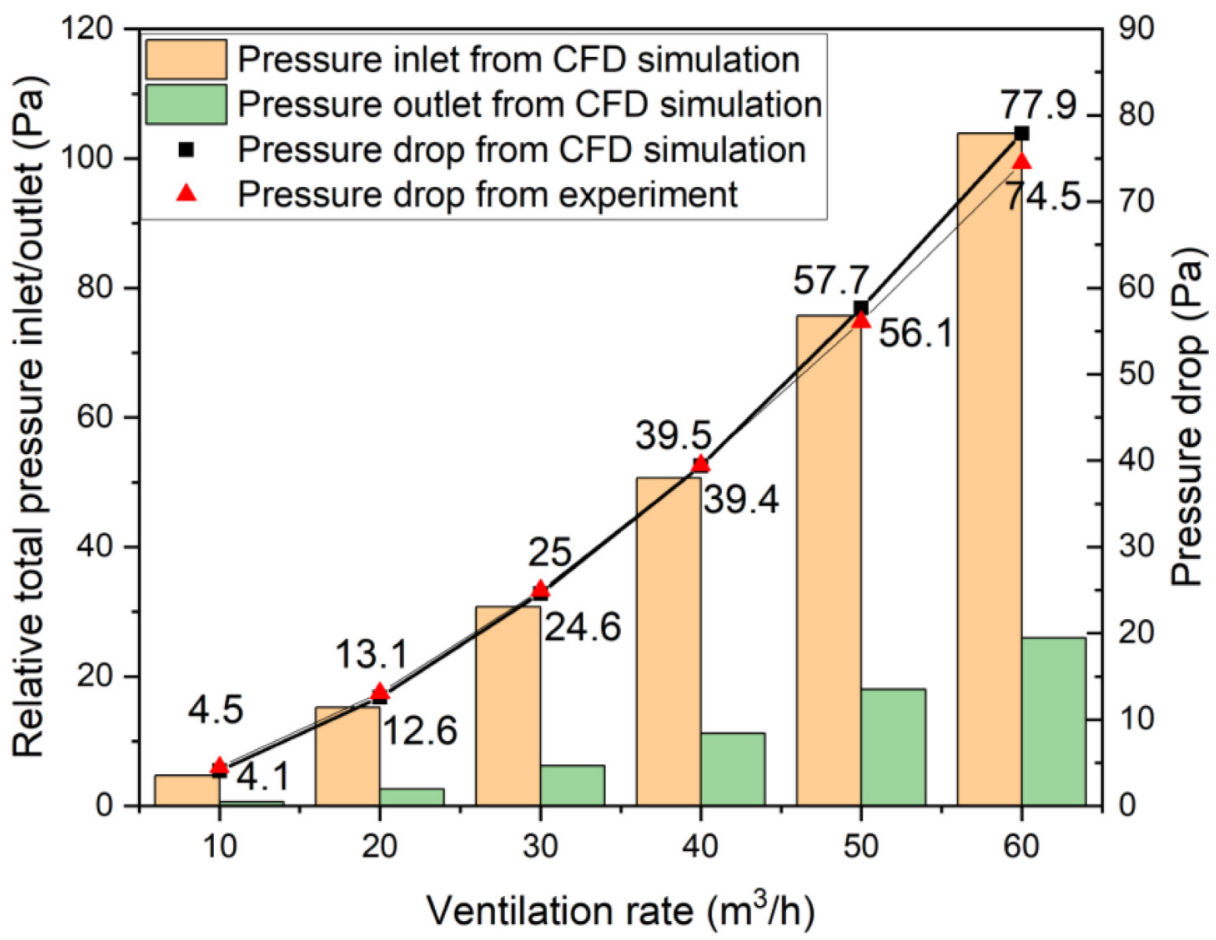

Fig. 16. System pressure drop under ventilation rates varied between $10-60 \mathrm{~m}^{3} / \mathrm{h}$.

\subsection{Energy performance in building}

Based on the IES VE baseline model, monthly heating demands are calculated using a 2-layer WHR system under various ventilation rates from $10 \mathrm{~m}^{3} / \mathrm{h}$ to $60 \mathrm{~m}^{3} / \mathrm{h}$, as shown in Fig. 17 , where the maximum heating demand occurred in December and the minimum in August. It is figured out that the increase of the ventilation rate could enlarge the monthly heating demand, where the maximum difference is $10.5 \mathrm{kWh} / \mathrm{m}^{2}$ in December by comparing $35.5 \mathrm{kWh} / \mathrm{m}^{2}$ and $46 \mathrm{kWh} / \mathrm{m}^{2}$ under ventilation rate of $10 \mathrm{~m}^{3} / \mathrm{h}$ and $60 \mathrm{~m}^{3} / \mathrm{h}$, respectively. However, in the summertime, the rise of ventilation rates have a limited impact on the monthly heating demand, where the monthly heating demand declines by $3.5 \mathrm{kWh} / \mathrm{m}^{2}$ from $6 \mathrm{kWh} / \mathrm{m}^{2}\left(60 \mathrm{~m}^{3} / \mathrm{h}\right)$ to $2.5 \mathrm{kWh} / \mathrm{m}^{2}\left(10 \mathrm{~m}^{3} / \mathrm{h}\right)$. Moreover, Table 5 indicates the impact of excluding and including the WHR system in the building baseline on the peaking heating power. Results reveal that the peak heating power could be reduced in a range of $3 \%$ to $24 \%$, with the ventilation rate increasing from $10 \mathrm{~m}^{3} / \mathrm{h}$ to $60 \mathrm{~m}^{3} / \mathrm{h}$. Meanwhile, the heating demand reduction rates vary between $10 \%$ to $20 \%$, with the ventilation rate increasing from $10-60 \mathrm{~m}^{3} / \mathrm{h}$. It is evident that the heating demand reduction rate has an increasing trend until reaching the maximum value of $20 \%$ with the ventilation rate of $40 \mathrm{~m}^{3} / \mathrm{h}$ by consuming $18 \mathrm{~W}$ fan power, then a slight declination to $18.7 \%$ with the ventilation rate of $60 \mathrm{~m}^{3} / \mathrm{h}$ consuming fan power of $34 \mathrm{~W}$. Nonetheless, the fan power continuously rises from $3 \mathrm{~W}$ to $34 \mathrm{~W}$, as depicted in Fig. 18. Therefore, the overall energy recovery performance of the WHR unit is optimised with a ventilation rate of $40 \mathrm{~m} 3 / \mathrm{h}$ and exacerbated with higher ventilation rates.

\subsection{Impact on the temperature and velocity}

The vertical and horizontal air temperature and velocity differences are investigated to analyse their distribution. It was determined by recording the temperature and velocity values at eight layers, representing distances from the WHR inlet between $0.5 \mathrm{~m}$ and $4.0 \mathrm{~m}$. In addition, five horizontal distances are 


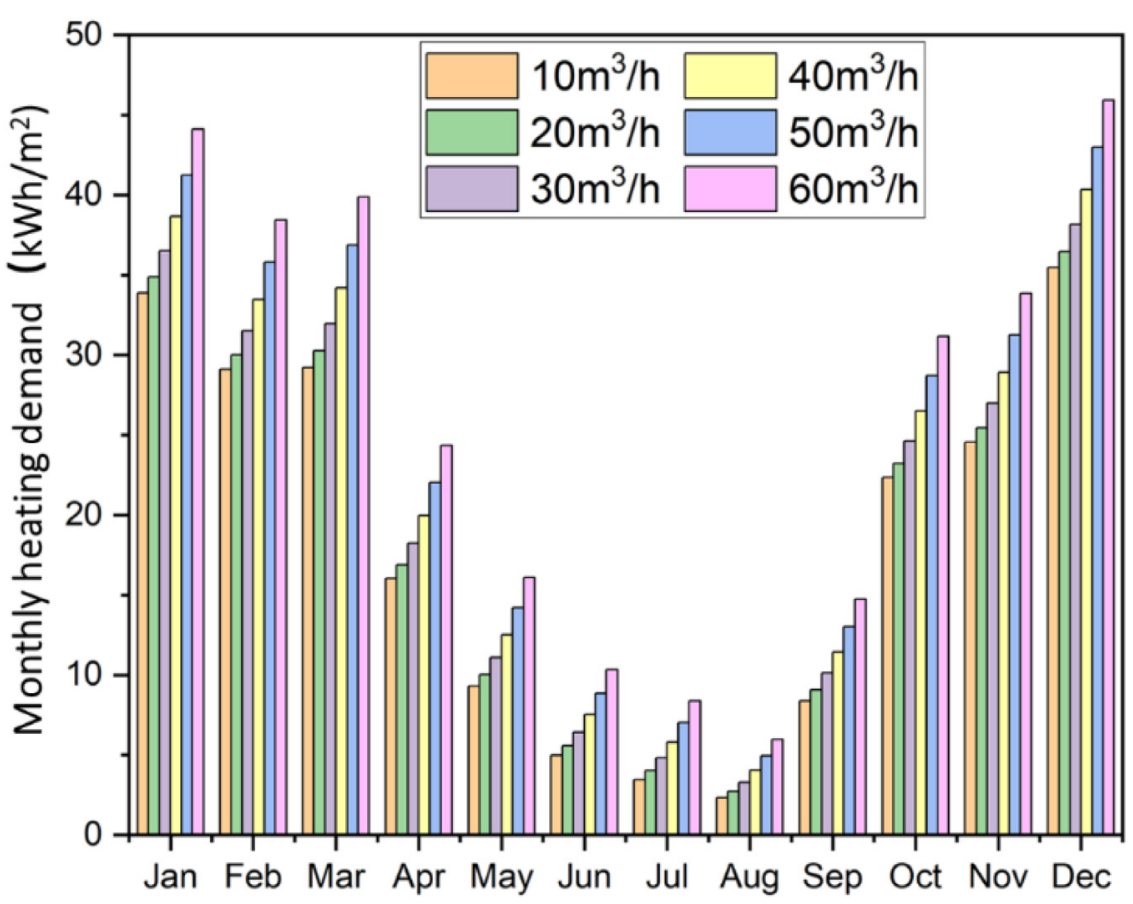

Fig. 17. Building monthly heating demand.

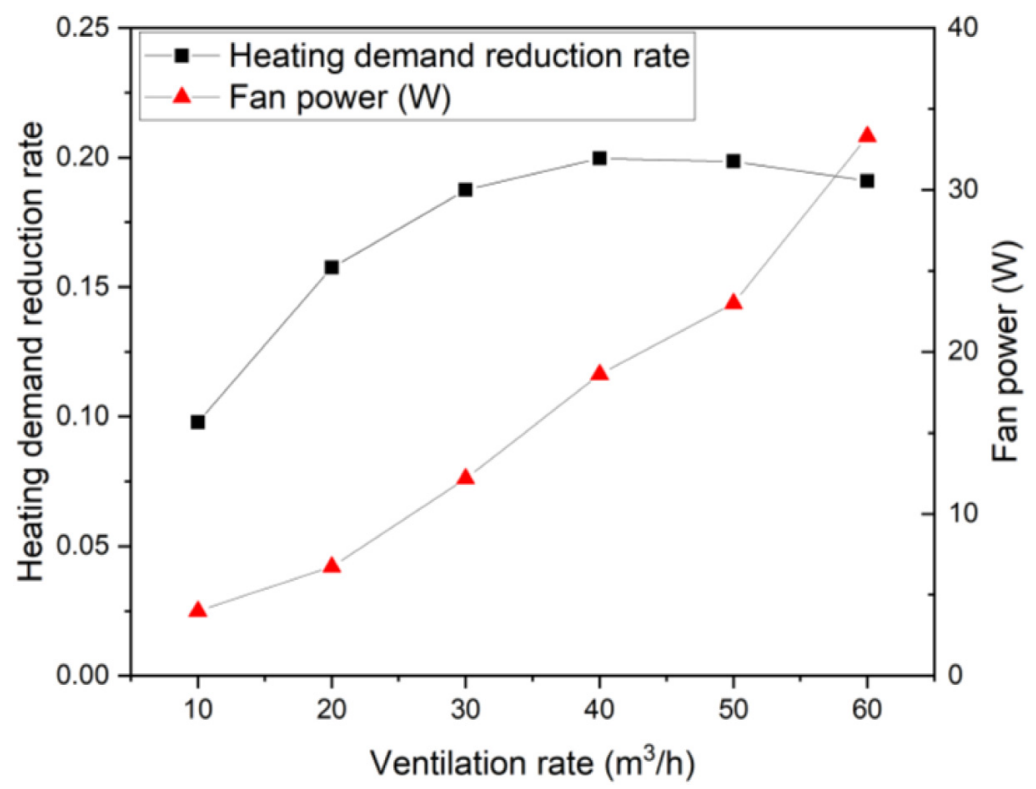

Fig. 18. Building space heating demand reduction rate and fan power with ventilation rates varied between 10 to $60 \mathrm{~m}^{3} / \mathrm{h}$.

also recorded in each layer. Firstly, the indoor air temperature, velocity distributions improvement are analysed by comparing the existence of the WHR system under the ventilation rate of $10 \mathrm{~m}^{3} / \mathrm{h}$, as shown in Fig. 19 (without) and Fig. 20(a) (with) the heat recovery. It is discovered that the maximum indoor air temperature difference drops from $4.5^{\circ} \mathrm{C}$ to $3{ }^{\circ} \mathrm{C}$, where the average temperature has a significant increase from $13.5^{\circ} \mathrm{C}$ to $22.5^{\circ} \mathrm{C}$. However, the maximum indoor air velocity rises from $0.47 \mathrm{~m} / \mathrm{s}$ to $0.9 \mathrm{~m} / \mathrm{s}$ due to the large pressure difference near the inlet region caused by the inlet-outlet backflow of the WHR system at $0.5 \mathrm{~m}$ vertical layer and $1.5 \mathrm{~m}$ horizontal distance. Additionally, the air velocity disturbance is weakened in the region away from the inlet.
Fig. 20 reveals the impact of the WHR ventilation rates on indoor air temperature, velocity distributions in terms of the air temperature and velocity distribution, under (a) $10 \mathrm{~m}^{3} / \mathrm{h}$, (b) $30 \mathrm{~m}^{3} / \mathrm{h}$ and (c) $60 \mathrm{~m}^{3} / \mathrm{h}$ air change rates. With the increment of the ventilation rate, the indoor air temperature rises to $22.5^{\circ} \mathrm{C}$, $23{ }^{\circ} \mathrm{C}$ and $23.3^{\circ} \mathrm{C}$, respectively. The air temperature disturbance is weakened with maximum indoor temperature differences reaching $2.8{ }^{\circ} \mathrm{C}, 2.5{ }^{\circ} \mathrm{C}$ and $2.2{ }^{\circ} \mathrm{C}$, respectively. On the contrary, the average indoor air velocity increases from $0.2 \mathrm{~m} / \mathrm{s}$ to $0.7 \mathrm{~m} / \mathrm{s}$ and $1.1 \mathrm{~m} / \mathrm{s}$, respectively, due to the rise of the ventilation rate. Besides, the air velocity disturbance is strengthened along with the increment of indoor air velocity. 

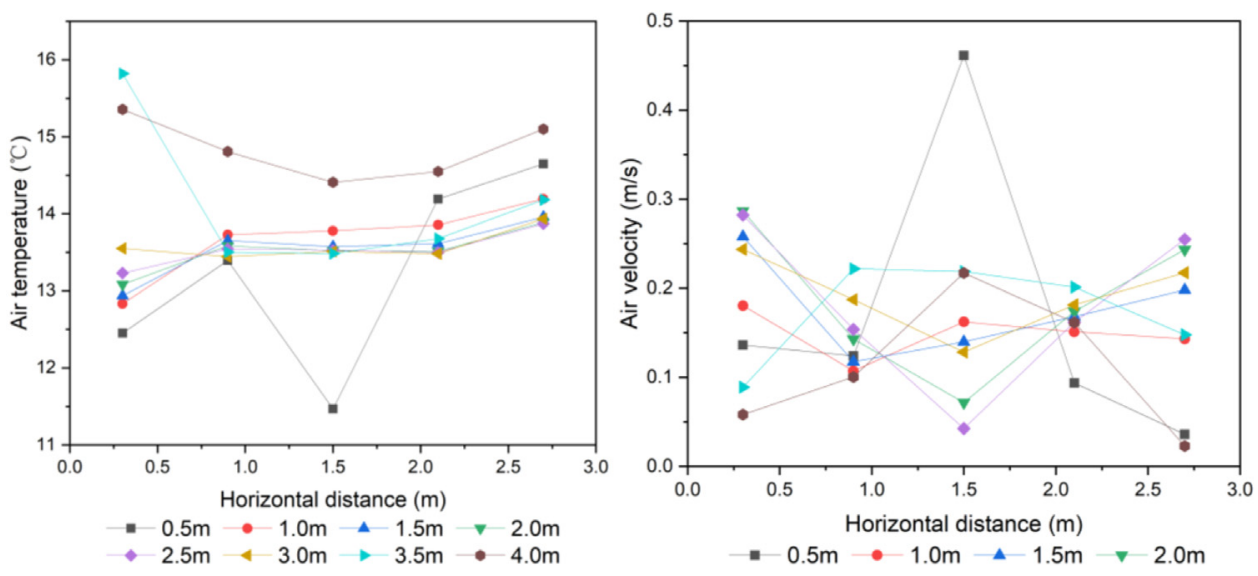

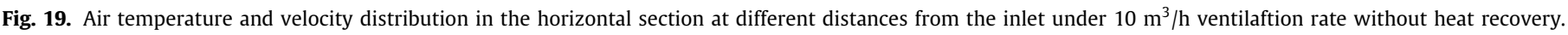

Table 5

The impact of ventilation rates on the peak heating power.

\begin{tabular}{llll}
\hline $\begin{array}{l}\text { Ventilation } \\
\text { rate }\left(\mathrm{m}^{3} / \mathrm{h}\right)\end{array}$ & $\begin{array}{l}\text { Excl/Incl. } \\
\text { WHR }\end{array}$ & $\begin{array}{l}\text { Peak heating } \\
\text { power }(\mathrm{W})\end{array}$ & $\begin{array}{l}\text { Power } \\
\text { reduction rate }\end{array}$ \\
\hline \multirow{2}{*}{10} & Excl. WHR & 6553 & $3 \%$ \\
& Incl. WHR & 6331 & \\
20 & Excl. WHR & 7269 & $13 \%$ \\
& Incl. WHR & 6322 & \\
30 & Excl. WHR & 7988 & $20 \%$ \\
& Incl. WHR & 6366 & \\
40 & Excl. WHR & 8707 & \\
& Incl. WHR & 6752 & $23 \%$ \\
50 & Excl. WHR & 9427 & \\
& Incl. WHR & 7223 & $24 \%$ \\
\hline \multirow{2}{*}{60} & Excl. WHR & 10147 & \\
& Incl. WHR & 7753 & \\
\hline
\end{tabular}

\section{Conclusions}

This work presents the numerical and experimental performance of the window heat recovery (WHR) system made of heat pipes. The numerical model is validated with the experiments and used to study the system for different working conditions and analyse its effect on energy performance in building and indoor air temperature, velocity distributions. The following conclusions can be drawn:

Thermal dynamic performance:

- The effectiveness of heat pipe-based window heat recovery could increase from $65 \%-95 \%$ with the decline of ventilation rate from 60 to $10 \mathrm{~m}^{3} / \mathrm{h}$ and temperature difference from 30 to $10{ }^{\circ} \mathrm{C}$ between exhausted and supplied air.

- Based on CFD simulation results, the numerical pressure drop and temperature difference results agree with the experiment, with the discrepancies ranging from $-4.4 \%$ to $9.8 \%$ and $2.4 \%$ to $3.2 \%$, respectively.

Building energy performance:

- The increase of the ventilation rate could enlarge the monthly heating demand, where the maximum difference is $10.5 \mathrm{kWh} / \mathrm{m}^{2}$ in December by comparing the ventilation rate of $10 \mathrm{~m}^{3} / \mathrm{h}$ and $60 \mathrm{~m}^{3} / \mathrm{h}$, respectively, whereas the rise of ventilation rates have a limited impact on the monthly heating demand in the summertime. However, the fan power continuously rises from 3 to $34 \mathrm{~W}$.
- The average temperature significantly increases from $13.5^{\circ} \mathrm{C}$ to $22.5{ }^{\circ} \mathrm{C}$ with different distances from the WHR inlet between $0.5 \mathrm{~m}$ and $4.0 \mathrm{~m}$. Nonetheless, the maximum indoor air velocity shows the contrary trend due to the inletoutlet backflow of the WHR system at $0.5 \mathrm{~m}$ vertical layer and $1.5 \mathrm{~m}$ horizontal distance. Additionally, the air velocity disturbance is affected by the distance from the inlet.

\section{Optimum sizing:}

- The overall energy recovery performance of installing the WHR unit is optimised with the ventilation rate of $40 \mathrm{~m}^{3} / \mathrm{h}$ by consuming $18 \mathrm{~W}$ fan power, reaching the maximum value of $20 \%$ heating demand reduction rate.

In addition to the its improvement of air quality in buildings, its use may reduce the daylighting area and acoustic insulation. The impact of this limitations will be addressed in future works.

The presented window heat recovery system could be applied to analyse and optimise the building retrofit packages in different climate regions. Considering that up to $90 \%$ of existing homes rely on ineffective natural and mechanical ventilation, providing clean and fresh air in existing homes remains a vast market demand. Therefore, tackling the carbon challenge in the building sector requires radical measures of effective WHR ventilation system to achieve decarbonisation and significant contribution to Net Zero Target in the UK and EU.

\section{CRediT authorship contribution statement}

Germilly Barreto: Methodology, Software, Data curation, Writing - original draft Investigation, Validation. Ke Qu: Conceptualisation, Methodology, Data curation, Investigation, Validation, Project administration. Yuhao Wang: Methodology, Writing review \& editing, Resources. Muriel Iten: Writing - review \& editing. Saffa Riffat: Supervision, Funding acquisition, Writing review \& editing.

\section{Declaration of competing interest}

The authors declare that they have no known competing financial interests or personal relationships that could have appeared to influence the work reported in this paper.

\section{Acknowledgements}

The authors would like to acknowledge the financial support and contributions from European Commission Horizon 2020 project Surefit (project contract number: 894511) and project partners participation. 

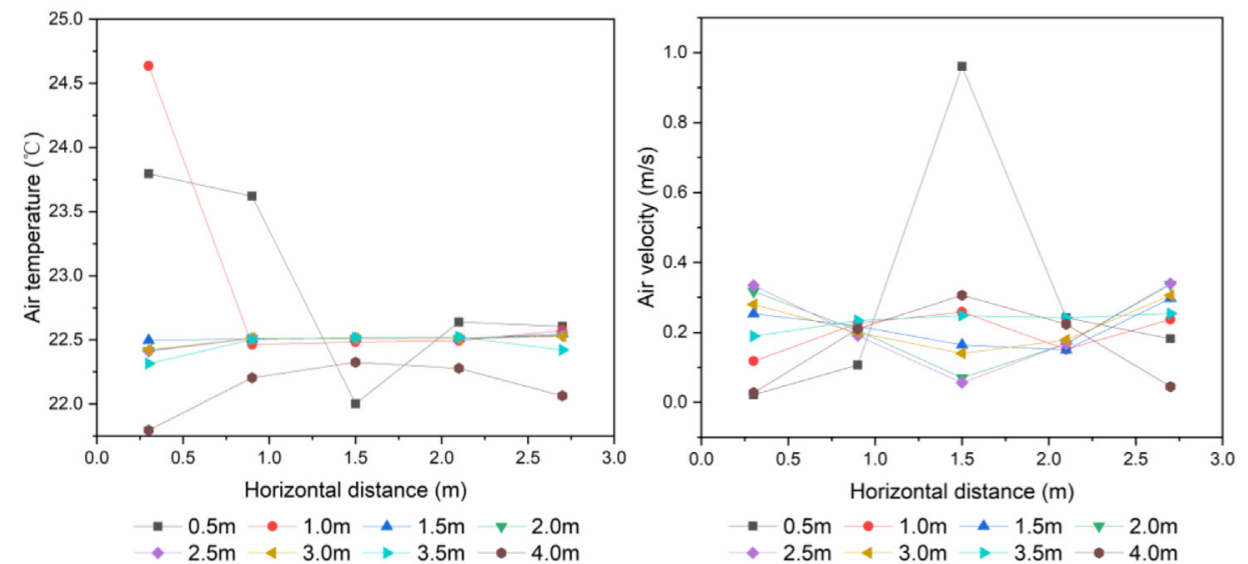

(a)
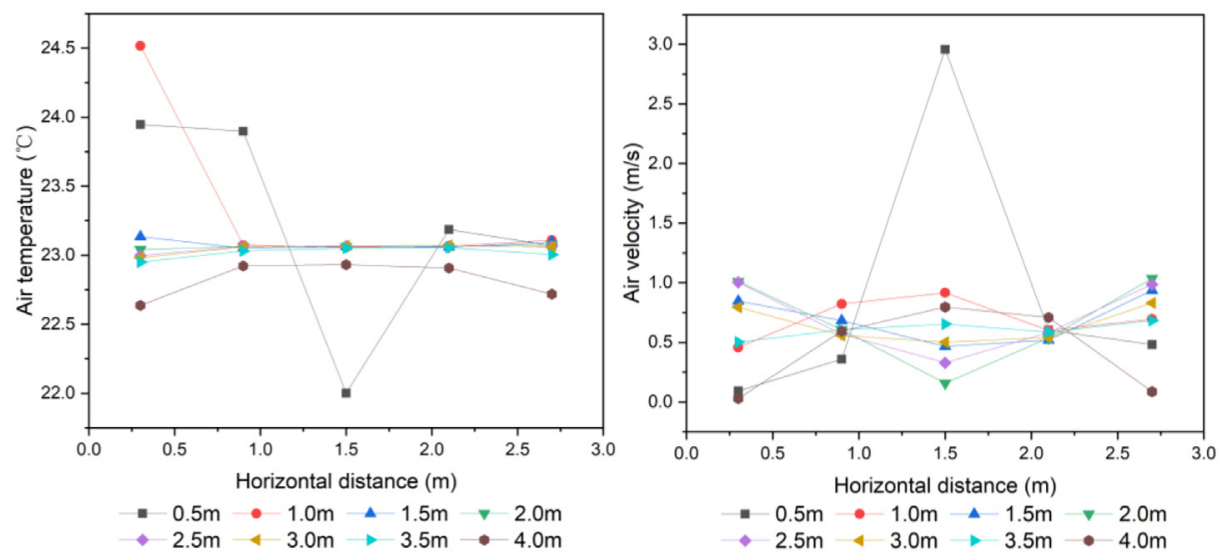

(b)
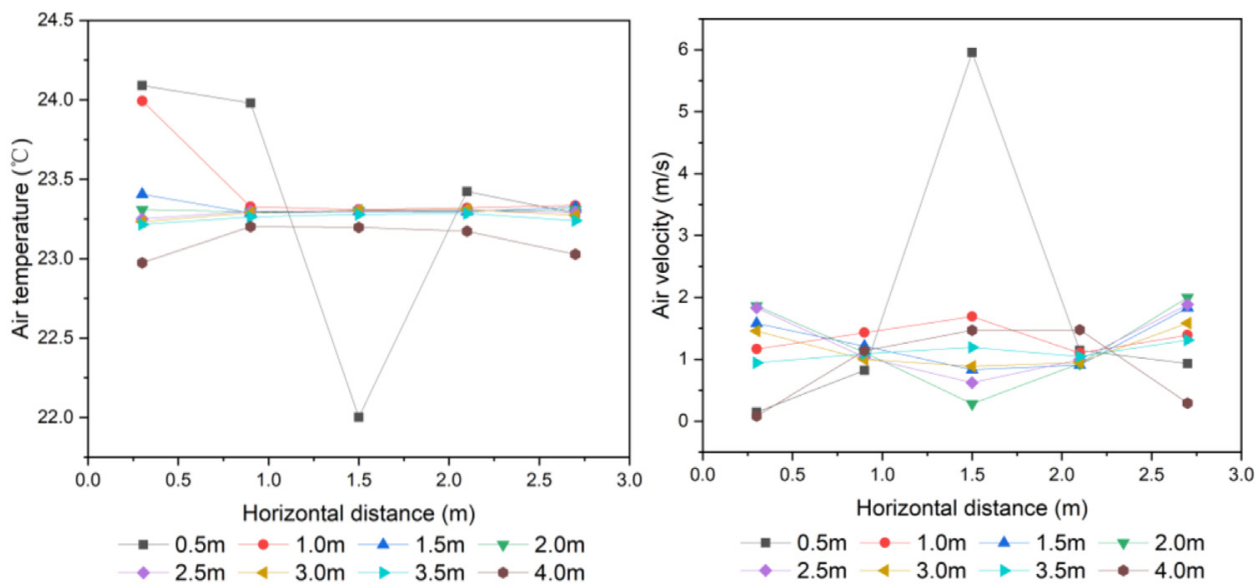

(c)

Fig. 20. Air temperature and velocity distribution in the horizontal section at different distances from the inlet under $10 \mathrm{~m}^{3} / \mathrm{h}(\mathrm{a}), 30 \mathrm{~m}^{3} / \mathrm{h}(\mathrm{b}) \mathrm{and} 60 \mathrm{~m}^{3} / \mathrm{h}(\mathrm{c})$ ventilation rates with heat recovery.

\section{References}

Andersson, B., Andersson, R., Håkansson, L., Mortensen, M., Sudiyo, R., Van Wachem, B., 2011. Computational Fluid Dynamics for Engineers. Cambridge University Press, Cambridge, http://dx.doi.org/10.1017/ CBO9781139093590.

2013. ANSYS Fluent User's Guide. ANSYS, Inc., Southpointe.

Babota, F., 2014. Mechanical Ventilation Systems with Heat Recovery for Refurbishment Projects and New Buildings. Bull. Polytech. Inst. Jassy.

Bang, M., Engelsgaard, S.S., Alexandersen, E.K., Riber Skydt, M., Shaker, H.R., Jradi, M., 2019. Novel real-time model-based fault detection method for automatic identification of abnormal energy performance in building ventilation units. Energy Build. 183, 238-251. http://dx.doi.org/10.1016/j.enbuild.2018. 11.006 .

Belmans, B., Aerts, D., Verbeke, S., Audenaert, A., Descamps, F., 2019. Set-up and evaluation of a virtual test bed for simulating and comparing singleand mixed-mode ventilation strategies. Build. Environ. 151, 97-111. http: //dx.doi.org/10.1016/j.buildenv.2019.01.027.

Biesiot, W., Noorman, K.J., 1999. Energy requirements of household consumption: A case study of The Netherlands. Ecol. Econ. 28, 367-383. http://dx.doi.org/ 10.1016/S0921-8009(98)00113-X.

Brozovsky, J., Simonsen, A., Gaitani, N., 2021. Validation of a CFD model for the evaluation of urban microclimate at high latitudes: A case study in 
Trondheim, Norway. Build. Environ. 205 (May), 108175. http://dx.doi.org/10. 1016/j.buildenv.2021.108175.

Calautit, J.K., Hughes, B.R., 2014a. Measurement and prediction of the indoor airflow in a room ventilated with a commercial wind tower. Energy Build. 84, 367-377. http://dx.doi.org/10.1016/j.enbuild.2014.08.015.

Calautit, J.K., Hughes, B.R., 2014b. Wind tunnel and CFD study of the natural ventilation performance of a commercial multi-directional wind tower. Build. Environ. 80, 71-83. http://dx.doi.org/10.1016/j.buildenv.2014.05.022.

Calautit, J.K., O'Connor, D., Hughes, B.R., 2014. Determining the optimum spacing and arrangement for commercial wind towers for ventilation performance. Build. Environ. 82, 274-287. http://dx.doi.org/10.1016/j.buildenv.2014.08. 024.

Calautit, J.K., O'Connor, D., Tien, P.W., Wei, S., Pantua, C.A.J., Hughes, B., 2020. Development of a natural ventilation windcatcher with passive heat recovery wheel for mild-cold climates: CFD and experimental analysis. Renew. Energy 160, 465-482. http://dx.doi.org/10.1016/j.renene.2020.05.177.

Cao, S.J., Ren, C., 2018. Ventilation control strategy using low-dimensional linear ventilation models and artificial neural network. Build. Environ. 144, 316-333. http://dx.doi.org/10.1016/j.buildenv.2018.08.032.

Capristo, C., Romei, I., Boner, A.L., 2004. Environmental prevention in atopic eczema dermatitis syndrome (AEDS) and asthma: Avoidance of indoor allergens. Allergy Eur. J. Allergy Clin. Immunol. Suppl. 59, 53-60. http: //dx.doi.org/10.1111/j.1398-9995.2004.00652.x.

Carlsson, M., Touchie, M., Richman, R., 2019. Investigating the potential impact of a compartmentalisation and ventilation system retrofit strategy on energy use in high-rise residential buildings. Energy Build. 199, 20-28. http://dx.doi. org/10.1016/j.enbuild.2019.06.035.

Chen, X., Qu, K., Calautit, J., Ekambaram, A., Lu, W., Fox, C., Gan, G., Riffat, S., 2020. Multi-criteria assessment approach for a residential building retrofit in Norway. Energy Build. 215, http://dx.doi.org/10.1016/j.enbuild.2019.109668.

Cho, H., Cabrera, D., Sardy, S., Kilchherr, R., Yilmaz, S., Patel, M.K., 2021. Evaluation of performance of energy efficient hybrid ventilation system and analysis of occupants' behavior to control windows. Build. Environ. 188, http://dx.doi.org/10.1016/j.buildenv.2020.107434.

Clarke, P., 2019. Module 141: MVHR for energy-efficient ventilation and summer cooling. CIBSE J.

Cuce, P.M., Riffat, S., 2015. A comprehensive review of heat recovery systems for building applications. Renew. Sustain. Energy Rev. 47, 665-682. http: //dx.doi.org/10.1016/j.rser.2015.03.087.

de Oliveira Fernandes, M.A., Keijzer, E., van Leeuwen, S., Kuindersma, P., Melo, L., Hinkema, M., Gonçalves Gutierrez, K., 2021. Material-versus energy-related impacts: Analysing environmental trade-offs in building retrofit scenarios in the Netherlands. Energy Build. 231, 110650. http://dx.doi.org/10.1016/j. enbuild.2020.110650.

Dodoo, A., 2020. Primary energy and economic implications of ventilation heat recovery for a multi-family building in a Nordic climate. J. Build. Eng. 31, 101391. http://dx.doi.org/10.1016/j.jobe.2020.101391.

Ekins, P., Lees, E., 2008. The impact of EU policies on energy use in and the evolution of the UK built environment. Energy Policy 36, 4580-4583. http://dx.doi.org/10.1016/j.enpol.2008.09.006.

Fabi, V., Andersen, R.V., Corgnati, S., Olesen, B.W., 2012. Occupants' window opening behaviour: A literature review of factors influencing occupant behaviour and models. Build. Environ. 58, 188-198. http://dx.doi.org/10. 1016/j.buildenv.2012.07.009.

Gedik, E., Yilmaz, M., Kurt, H., 2016. Experimental investigation on the thermal performance of heat recovery system with gravity assisted heat pipe charged with R134a and R410a. Appl. Therm. Eng. 99, 334-342. http://dx.doi.org/10. 1016/j.applthermaleng.2015.12.075.

González Couret, D., Rodríguez Díaz, P.D., Abreu de la Rosa, D.F., 2013. Influence of architectural design on indoor environment in apartment buildings in Havana. Renew. Energy 50, 800-811. http://dx.doi.org/10.1016/j.renene.2012. 07.043 .

H. Government, 2010. The Building Regulations 2010 Ventilation: Approved Document F - Means of Ventilation.

Guerra Santin, O., Itard, L., Visscher, H., 2009. The effect of occupancy and building characteristics on energy use for space and water heating in Dutch residential stock. Energy Build. 41, 1223-1232. http://dx.doi.org/10.1016/j. enbuild.2009.07.002.

Hall, M.R., Casey, S.P., Loveday, D.L., Gillott, M., 2013. Analysis of UK domestic building retrofit scenarios based on the E.ON Retrofit Research House using energetic hygrothermics simulation - Energy efficiency, indoor air quality, occupant comfort, and mould growth potential. Build. Environ. 70, 48-59. http://dx.doi.org/10.1016/j.buildenv.2013.08.015.

Kang, I., McCreery, A., Azimi, P., Gramigna, A., Baca, G., Abromitis, K., Wang, M., Zeng, Y., Scheu, R., Crowder, T., Evens, A., Stephens, B., 2021. Indoor air quality impacts of residential mechanical ventilation system retrofits in existing homes in Chicago, IL. Sci. Total Environ. 804, 150129. http://dx.doi. org/10.1016/j.scitotenv.2021.150129.

Krieger, J., Higgins, D.L., 2002. Housing and health: Time again for public health action. Am. J. Public Health 92, 758-768. http://dx.doi.org/10.2105/AJPH.92. 5.758 .
Li, W., Wang, S., 2020. A multi-agent based distributed approach for optimal control of multi-zone ventilation systems considering indoor air quality and energy use. Appl. Energy 275, 115371. http://dx.doi.org/10.1016/j.apenergy. 2020.115371.

Lim, A.Y., Yoon, M., Kim, E.H., Kim, H.A., Lee, M.J., Cheong, H.K., 2021. Effects of mechanical ventilation on indoor air quality and occupant health status in energy-efficient homes: A longitudinal field study. Sci. Total Environ. 785, 147324. http://dx.doi.org/10.1016/j.scitotenv.2021.147324.

Mardiana-Idayu, A., Riffat, S.B., 2012. Review on heat recovery technologies for building applications. Renew. Sustain. Energy Rev. 16, 1241-1255. http: //dx.doi.org/10.1016/j.rser.2011.09.026.

Nasif, M., Al-Waked, R., Morrison, G., Behnia, M., 2010. Membrane heat exchanger in HVAC energy recovery systems, systems energy analysis. Energy Build. 42, 1833-1840. http://dx.doi.org/10.1016/j.enbuild.2010.05.020.

National Institute for Health and Welfare (THL), 2013. HealthVent Health-Based Ventilation Guidelines for Europe (Deliverable 8: Report on the Impact of Guideline Implementation on Health and Energy).

Nóbrega, C.E.L., Brum, N.C.L., 2009. Modeling and simulation of heat and enthalpy recovery wheels. Energy 34, 2063-2068. http://dx.doi.org/10.1016/j.energy. 2008.08.016.

Paone, A., Bacher, J.P., 2018. The impact of building occupant behavior on energy efficiency and methods to influence it: A review of the state of the art. Energies 11, http://dx.doi.org/10.3390/en11040953.

Pitarma, R., Marques, G., Ferreira, B.R., 2017. Monitoring indoor air quality for enhanced occupational health. J. Med. Syst. 41, 1-8. http://dx.doi.org/10. 1007/s10916-016-0667-2.

Rasheed, E.O., Byrd, H., Money, B., Mbachu, J., Egbelakin, T., 2017. Why are naturally ventilated office spaces not popular in New Zealand? Sustain. 9, 1-16. http://dx.doi.org/10.3390/su9060902.

Romero-Méndez, R., Sen, M., Yang, K.T., McClain, R., 2000. Effect of fin spacing on convection in a plate fin and tube heat exchanger. Int. J. Heat Mass Transfer 43, 39-51. http://dx.doi.org/10.1016/S0017-9310(99)00120-9.

Seyyedvalilu, H., 2021. Difference between standard and realisable k-epsilon model. https://www.researchgate.net/post/Difference-between-standardand-realizable-k-epsilon-model (accessed September 28, 2021).

Shao, L., Riffat, S.B., Gan, G., 1998. Performance of heat recovery in passive stack ventilation systems. In: CIBSE Natl. Conf.. pp. 174-181.

Shen, S., Cai, W., Wang, X., Wu, Q., Yon, H., 2017. Investigation of liquid desiccant regenerator with fixed-plate heat recovery system. Energy 137, 172-182. http://dx.doi.org/10.1016/j.energy.2017.07.024.

Simonson, C., 2005. Energy consumption and ventilation performance of a naturally ventilated ecological house in a cold climate. Energy Build. 37, 23-35. http://dx.doi.org/10.1016/j.enbuild.2004.04.006.

Smith, K.M., Svendsen, S., 2016. The effect of a rotary heat exchanger in roombased ventilation on indoor humidity in existing apartments in temperate climates. Energy Build. 116, 349-361. http://dx.doi.org/10.1016/j.enbuild. 2015.12.025.

Stark, J.R., Bergman, T.L., 2017. Prediction of convection from a finned cylinder in cross flow using direct simulation, turbulence modeling, and correlationbased methods. Numer. Heat Transfer A 71, 591-608. http://dx.doi.org/10. 1080/10407782.2016.1277929.

Stark, J.R., Sharifi, N., Bergman, T.L., Faghri, A., 2016. An experimentally verified numerical model of finned heat pipes in crossflow. Int. J. Heat Mass Transfer 97, 45-55. http://dx.doi.org/10.1016/j.ijheatmasstransfer.2016.01.051.

Tian, Z., Yang, L., Wu, X., Guan, Z., 2020. A field study of occupant thermal comfort with radiant ceiling cooling and overhead air distribution system. Energy Build. 223, 109949. http://dx.doi.org/10.1016/j.enbuild.2020.109949.

Tien, P.W., Wei, S., Liu, T., Calautit, J., Darkwa, J., Wood, C., 2021. A deep learning approach towards the detection and recognition of opening of windows for effective management of building ventilation heat losses and reducing space heating demand. Renew. Energy 177, 603-625. http://dx.doi.org/10.1016/j. renene.2021.05.155.

Vali, A., Simonson, C.J., Besant, R.W., Mahmood, G., 2009. Numerical model and effectiveness correlations for a run-around heat recovery system with combined counter and cross flow exchangers. Int. J. Heat Mass Transfer 52, 5827-5840. http://dx.doi.org/10.1016/j.ijheatmasstransfer.2009.07.020.

Wallin, J., Claesson, J., 2014. Improving heat recovery using retrofitted heat pump in air handling unit with energy wheel. Appl. Therm. Eng. 61, 823-829. http://dx.doi.org/10.1016/j.applthermaleng.2013.09.059.

Wang, J.C.Y., 1985. Practical thermal design of run-around air-to-air heat recovery system. Heat Recover. Syst. 5, 493-501.

Wang, Q., Ploskić, A., Song, X., Holmberg, S., 2016. Ventilation heat recovery jointed low-temperature heating in retrofitting - An investigation of energy conservation, environmental impacts and indoor air quality in Swedish multifamily houses. Energy Build. 121, 250-264. http://dx.doi.org/10.1016/ j.enbuild.2016.02.050.

Wood, A., Salib, R., 2013. Guide to Natural Ventilation in High Rise Office Buildings. http://dx.doi.org/10.4324/9780203720042. 
Yassine, B., Ghali, K., Ghaddar, N., Srour, I., Chehab, G., 2012. A numerical modeling approach to evaluate energy-efficient mechanical ventilation strategies. Energy Build. 55, 618-630. http://dx.doi.org/10.1016/j.enbuild.2012.08.042.

Yau, Y.H., Ahmadzadehtalatapeh, M., 2010. A review on the application of horizontal heat pipe heat exchangers in air conditioning systems in the tropics. Appl. Therm. Eng. 30, 77-84. http://dx.doi.org/10.1016/j.applthermaleng. 2009.07.011.

Young, M., Less, B.D., Dutton, S.M., Walker, I.S., Sherman, M.H., Clark, J.D., 2020. Assessment of peak power demand reduction available via modulation of building ventilation systems. Energy Build. 214, 109867. http://dx.doi.org/ 10.1016/j.enbuild.2020.109867.

Yuan, Y., Luo, Z., Liu, J., Wang, Y., Lin, Y., 2018. Health and economic benefits of building ventilation interventions for reducing indoor PM2.5 exposure from both indoor and outdoor origins in urban Beijing, China. Sci. Total Environ. 626, 546-554. http://dx.doi.org/10.1016/j.scitotenv.2018.01.119.
Zender-świercz, E., 2021. A review of heat recovery in ventilation. Energies 14 http://dx.doi.org/10.3390/en14061759.

Zhang, S., Ai, Z., Lin, Z., 2021. Novel demand-controlled optimisation of constant-air-volume mechanical ventilation for indoor air quality, durability and energy saving. Appl. Energy 293, 116954. http://dx.doi.org/10.1016/j. apenergy.2021.116954.

Zhu, M., Huang, J., Song, M., Hu, Y., 2020. Thermal performance of a thin flat heat pipe with grooved porous structure. Appl. Therm. Eng. 173, 115215. http://dx.doi.org/10.1016/j.applthermaleng.2020.115215.

Zuazua-Ros, A., Martín-Gómez, C., Ibañez-Puy, E., Vidaurre-Arbizu, M., Gelbstein, Y., 2019. Investigation of the thermoelectric potential for heating, cooling and ventilation in buildings: Characterisation options and applications. Renew. Energy 131, 229-239. http://dx.doi.org/10.1016/j.renene.2018. 07.027 . 